\title{
Meltblown technology for production of polymeric micro/nano fibers: A Review
}

\author{
Jiri Drabek and Martin Zatloukal* \\ Polymer Centre, Faculty of Technology, Tomas Bata University in Zlín, \\ Vavrečkova 275, 76001 Zlín, Czech Republic
}

Keywords: Meltblown, polymeric nanofibers, nonwoven, flow instabilities

*Corresponding author: mzatloukal@utb.cz 


\begin{abstract}
This work summarizes the current state of knowledge in area of meltblown technology for production of polymeric nonwovens with specific attention to utilized polymers, die design, production of nanofibers, the effect of process variables (such as throughput rate, melt rheology, melt temperature, die temperature, air temperature/velocity/pressure and die-to-collector distance and speed) with relation to nonwoven characteristics as well as to typical flow instabilities such as whipping, die drool, fiber breakup, melt spraying, flies, generation of small isolated spherical particles, shots, jam and generation of nonuniform fiber diameters.
\end{abstract}




\section{INTRODUCTION}

Carlton Francis was the first person who tried to develop microfibers. In 1939 he pictured a spray gun as an instrument for production of textile like microfibers. Since 1940's to mid. 1960's three companies (American Viscose, Dow Chemical Company and Chemstrand Company) were trying to develop microfibers by using a spray spinning technique. However, none of these companies achieved their expected results and thus, they discontinued research on the projects. In the early 1950's, meltblown (MB) technology was developed under the United States Army Chemical Warfare Laboratories based on the previous Dow's research on production of microfibers [1]. In 1954, Van A. Wente together with his colleagues were the first, who demonstrated the concept of melt blowing process for thermoplastic polymers, that formed microfibers or fibers having less than 10 microns in diameter. Wente et al. conducted their research at the United States Naval Research Laboratory to develop microfibers in order to produce filters on drone aircraft used to monitor radiation from US and Russian nuclear tests [2]. During the 1960's, Esso Research and Engineering Company (now ExxonMobil Corporation) followed Wente's work and they were able to improve and scale up the line considerably (from 3 to 40 inches die width) to successfully produce low-cost polypropylene (PP) microfibers [1]. Progress in production throughput rates was obvious, Wente achieved production rates of $1.5 \times 10^{-4}-4.5 \times 10^{-4}$ $\mathrm{kg} / \mathrm{s} / \mathrm{m}$ (i.e. kilograms per second for one meter of die width) whereas Esso was able to increase throughput levels of $6.5 \times 10^{-3}-12.9 \times 10^{-3} \mathrm{~kg} / \mathrm{s} / \mathrm{m}$ of die width, which has made MB technology commercially attractive [3]. In addition, Esso focused on redesigning of original Wente's die to minimize flow instability known as "shots" [1]. At the beginning, the attention was payed to production of meltblown battery separators and synthetic electrical paper utilizing a 3-ply calendered PP laminate developed by Exxon [4]. The "Meltblown Process" was patented by Esso in the mid-1960's [1]. Exxon's affiliate in Japan retained the right to commercialize the technology and did so quite 
successfully by producing and marketing Tapyrus MB products and became one of the earliest commercial melt blowing process practitioners. To summarize it, Wentes` concept of practical onestep process to fabricate nonwovens webs, tow, bats, etc. was at first demonstrated, patented, publicized and licensed by Exxon company [2]. In the 1970's, Exxon ensured and extensive patent position for $\mathrm{MB}$, in the same time they recognized potential of combining MB webs with other webs produced for example by spunbond technology, especially for reinforcement, through laminations and coating. They identified as well possibilities of use MB webs in filtration output, hygiene products, adhesive webs, cigarette filters and special synthetic papers [4]. Due to further research utilization and production the resin for the MB process, the Exxon company licensed the process out to other companies: KimberlyClark, Johnson \& Johnson, James River, Web Dynamics, Ergon Nonwoven, Riegel, and Dewey \& Almy [1]. In 1983, Esso started the cooperation with the University of Tennessee, Knoxville and built the first pilot line to ensure continuing research in the MB process [1]. From 1970 to 2000, over 320 U.S. patents have been granted to the technologies and products related to melt blowing. In the 70's just 20 patents were granted; in the 80's the number of patents increased to 64 and in 90 's it jumped to 236 patents. It is obvious that the field of utilization of MB technology is constantly expanding [5]. Development of publication activity about nanofibers, nonwovens and meltblown from the 70's until June 2019 is displayed in Figure 1.

The paper is organized as follows. First, the melt blown process together with key processing/rheological variables and important characteristics of produced webs are introduced and summarized. Second, current state of knowledge in area of polymeric nanofibers production via meltblown technology is provided. Finally, flow instabilities and defects occurring in meltblown technology are described and discussed. 


\section{MELTBLOWN TECHNOLOGY}

Melt blowing, as shown in Figure 2, is a simple, versatile and one step process for converting polymeric raw materials into nonwovens. MB process includes five constituents that are the extruder, metering pump, die assembly, web formation and winding $[1,8]$. The polymer in the form of pellets, granules, powder or chips is gravity-fed from hopper to the extruder at a certain feed rate $[8,9,10]$. The extruder supplies the melt to the metering pump.

The metering pump, known also as gear pump provides the polymer melt delivery to a die assembly uniformly and consistently. Die assembly can be considered as the most important part of the MB system, which is responsible for the quality of the produced fibers [1, 8]. A die assembly consists of a polymer feed distribution system, such as a Coat-hanger, T-die or Fishtail die, to provide even polymer flow and residence time across the width of the MB die, a nose tip which could be also several types with different designs for example slot die, annular die (swirl die), HILL die, AGR die and so on, and air manifolds $[1,11]$. An air assembly provides air streams with different temperatures reaching typically $50-80 \%$ of sound speed $[1,12,13]$. A polymer in the form of melt is extruded through small orifices into converging streams of hot air $[10,14,15]$. The drag force of the air causes rapid melt elongation into a fine fiber with a small diameter $[10,14,15]$, as it is depicted in Figure 3. Typical change in fiber diameter (expressed here as the ratio of die to final fiber diameter), is between 250 (from $0.4 \mathrm{~mm}$ down to $1.6 \mu \mathrm{m}$ [16]) and $667(0.2 \mathrm{~mm}$ down to $300 \mathrm{~nm} \mathrm{[18])} \mathrm{for} \mathrm{isotactic}$ polypropylenes. It was reported that the highest fiber diameter reduction occurs at very small post die distances (typically between 10 and $20 \mathrm{~mm}$ ) and very short times $(0.05 \mathrm{~ms})$ [19, 20, 21, 22]. During fiber attenuation, very high extensional strain rates $\left(\sim 10^{6} \mathrm{~s}^{-1}\right)$ are achieved [23]. The air streams, typically having the same temperature as the polymer melt, also help to transport fibers to a collector 
[14]. Due to heat transfer and mixing with the surrounding air, the air temperature exponentially decreases between die and collector [24], which leads to fiber solidification. Cooling rates are typically in the range $10^{3}-10^{4} \mathrm{C} / \mathrm{s}$, as can be deduced from fiber speed and velocity profiles reported in [25, 26]. The collector picks up the attenuated filament streams, which leads to a nonwoven web formation with an almost random network of fibers [1]. At the end, the nonwoven web is wound into a cylindrical package for easier subsequent handling $[1,5]$. Table 1 and Figure 4 summarize development in MB die design in chronological order.

The MB technology is rather complex process, in which there are many different variables having impact on produced nonwovens such as polymer throughput, melt temperature, melt viscosity, air speed, air pressure, air temperature, die to collector distance (DCD), collector speed, die temperature and type of the die. Tables 2 and 3 show trends and conclusions that have been discovered for the last three decades. From the performed summarization, it can be concluded that the average fiber diameter of produced nonwovens mainly depends on the throughput rate, melt viscosity, melt temperature, air temperature and air velocity.

\section{MELTBLOWN WEBS}

MB fabric properties can be adapted depending on end-use requirements by adjusting polymer section, process conditions, bonding and finishing processes. Basic characteristics and properties of MB produced webs are provided bellow $[89,90]$.

- Random fiber orientation

- Low to moderate web strength, which is typically characterized by tenacity, Young's modulus and elongation at break. Typical machine direction values for webs with basic weights between $12-$ 
$65 \mathrm{~g} / \mathrm{m}^{2}$ made from homopolypropylene (with weight average molecular weight $238 \mathrm{~kg} / \mathrm{mol}$ and polydispersity index 5) at extrusion temperature $332{ }^{\circ} \mathrm{C}$ and $\mathrm{DCD}=33.7 \mathrm{~cm}$ are following [54]: tenacity is $11.4-14.3 \mathrm{MPa}$, Young's modulus is $0.32-0.43 \mathrm{GPa}$ and elongation at break is 16.7 $-60.8 \%$. Strength of MB webs is derived from mechanical entanglements and frictional forces and their basis weight is given by the number of layers.

- Generally, the webs have high covering power (i.e. low transparency due to light diffraction and lustre of a fabric) [91]).

- Fiber diameter ranges between 0.5 and $30 \mu \mathrm{m}$, but the typical range is 2 to $7 \mu \mathrm{m}$ (or 1 to $2 \mu \mathrm{m}$ [3, $14,18,69])$.

- $\quad$ Basis weight ranges between 8 and $350 \mathrm{~g} / \mathrm{m}^{2}$, typically $20-200 \mathrm{~g} / \mathrm{m}^{2}$.

- Microfibers provide high surface areas for good insulator and filter characteristics.

- The fibers have a smooth surface texture, appear to be circular in cross-section and vary in diameter along a single fiber (see Figure 5).

- Close examination of approximately 800 photomicrographs showed no 'fiber-ends' (except a few near areas where 'shot' is present), therefore, the fibers are believed to be mostly continuous in length.

A lot of different polymeric materials can be processed by melt blowing process, however PP is the most commonly used due to its ease of processing and suitability for end-use. PP accounts for $70 \%$ of the spunlaid resins used to manufacture nonwovens in North America. A typical PP used for melt blowing would have a melt flow index (MFI) between $30-1,500 \mathrm{~g} / 10$ minutes [89]. PP is one of the most widely used resin in nonwoven sector due to the following properties [13]:

- low density enabling lightweight fabrics to be made (density of crystalline phase is 0.932 $-0.943 \mathrm{~g} / \mathrm{cm}^{3}$, density of the amorphous phase is $\left.0.85 \mathrm{~g} / \mathrm{cm}^{3}[94]\right)$, 
- low glass transition $\left(\mathrm{Tg}=-13{ }^{\circ} \mathrm{C}\right.$ [91]) and melting temperature $\left(\mathrm{Tm}=165{ }^{\circ} \mathrm{C}[94]\right)$, economical for thermal bonding (between 125 and $155^{\circ} \mathrm{C}$ ) [89],

- inherent hydrophobicity (water absorption only $0.01 \%$ ) [94]

- good bulk (i.e. high thickness per unit weight) and covering power,

- chemical stability (resistant to most organic solvents, acids and bases) [94],

- resistance to mildew and perspiration,

- resistance to soiling (typically determined by means of actual wear and wash tests) [91],

- good mechanical strength and abrasion resistance. Tensile (Young's) modulus is 1.1 $2 \mathrm{GPa}$, tensile strength break is $30-40 \mathrm{MPa}$ and the elongation at break is $100-600 \%$ [95].

However, many different types of thermoplastic polymers are used in the MB process, some more than others. The polymers which are summarized in Table 4 have been used for production of nonwovens via MB technology. Blends of different polymer types and configurations are now tailored towards the end-user's requirements. Also there are several additives incorporated during the resin manufacturing process to supply various grades of the same polymer with large differences in their melt flow rates $[1,4,89,97,98]$. Addition of different additives into raw polymers was also shown to enhance properties of MB nonwovens. For example, it has been shown that addition of a nucleating agent magnesium stearate [99], dielectric barium titanate [100], perlite [101], stearate or modified rosin [102] into the PP polymer during the MB process can enhance filtration characteristics and stability of produced nonwovens. There is also possibility to produce cross-linked MB samples with an enhanced chemical and thermal resistance in comparison with their thermoplastic analogs [103, 104]. The crosslinks in the produced MB nonwovens can be irreversible [105 - 111] or thermoreversible [104, 
112 - 120] depending on the polymer and procedure used. Montgomery et al. [105] has shown that permanent crosslinks can be introduced by ultraviolet (UV) irradiation applied on produced MB fibers made from a linear amorphous polyester having UV-cross-linkable stilbene groups. On the other hand, thermally reversible crosslinked meltblown fibers were recently produced from Diels-Alder polymer networks comprised of methacrylate-based backbones covalently bonded by dynamic furan-maleimide linkages [121] (heat resistance up to $\sim 100{ }^{\circ} \mathrm{C}$ ) or from linear anthracene-functionalized acrylic polymers irradiated with UV light having the heat resistance up to about $180{ }^{\circ} \mathrm{C}$ [122]. Produced reversibly cross-linked fibers have an average diameter typical for $\mathrm{MB}$ and can be easily reprocessed/recycled into bulk materials.

Production of nonwovens began more than two decades ago; the industry remains to be the fastest growing sectors of textile materials in the world. Worldwide production grew from about 2.6 million tons in 1996 , worth about $\$ 10$ billion, to around 8.9 million tons in 2014 , worth $\$ 35.6$ billion, and is predicted to reach to 12.4 million tons by 2020 [96]. Meltblown nonwoven represents an important fraction (i.e., more than $10 \%$ ) of the $\$ 50$ billion global nonwovens market [121]. Due to the increasing trend of nonwoven fabric utilization, the introduction of biodegradable, sustainable raw products to create nonwovens remains unchanged. Nonwovens have unique properties such as strength, elongation, resilience, liquid repellency, softness, washability, filtering capacity, bacteria barrier, and sterility. Therefore, MB webs have a lot of applications, but it is remarkable that, nearly two-thirds demand of nonwoven fabrics are disposable products $[96,98]$. The most typical MB products, together with their application fields, are provided in Table 5. MB technology is also utilized in area of battery separators [4, 124], oil sorbents [125], bone tissue engineering [126] and filtration [9, 69, 127, 128].

It is useful to combine $\mathrm{MB}$ technology to other nonwoven processes (such as spunbond) that directly produce fibrous web structure because MB fibers have usually low physical properties due to 
suppressed polymer orientation (as the result of high temperature air, which generates the attenuation force at the die exit). In the spunbond process, cool air (directed across the filament bundle) is firstly used to cause filaments solidification and then, the filaments are stretched in the tapered conduit by high velocity air, i.e. the polymer is stretched after the cooling, which leads to its orientation enhancing physical properties but it is not suitable to form micro or nanofibers [13]. Basic characteristics of spunbond webs are following [13,89]: basic weight is between $5-800 \mathrm{~g} / \mathrm{m}^{2}$, fiber diameter ranges between $1-50 \mu \mathrm{m}$ (typically $15-35 \mu \mathrm{m}$ ), high strength-to-weight ratios and tear strength compared to other nonwovens. Combination of spunbond and meltblown webs during producing stage helps to obtain a variety of composite structures for protective applications especially in the hygiene and medical sectors. The Spunbond-Meltblown-Spunbond (SMS) is composite structure, where the spunbond webs provide the strength and the abrasion resistance and the MB web furnishes the liquid and particular barrier. Typical SMS structure is displayed in Figure 6. Merging of Spunbond and Meltblown webs has become a common practice in spunbond manufacturing. There are different combinations of spunbond-meltblown webs, such as Spunbond-Meltblown-Spunbond (SMS), Spunbond-Meltblown-Meltblown-Spunbond (SMMS), Spunbond-Spunbond-Meltblown-MeltblownSpunbond (SSMMS) composite nonwovens where comparatively weaker meltblown fiber are situated between the stronger spunbond filaments and others depending on the desirable final products properties $[13,89,129]$. These sandwiched structures of spunbond and meltblown nonwoven layers supply advantages such as fine filtration, low pressure drop and acoustic insulation etc. [13] 


\section{MELTBLOWN NANOFIBERS}

In the last years, the interest and consumption of polymeric nanofibers has increased greatly due to their extremely high surface area to weight ratio, high porosity, appreciable mechanical strength, and flexibility in functionalization [130 - 134]. Several different definitions of nanofibers exist depending on the application area. For example, The National Science Foundation (NSF) defines nanofiber as follows: "nanofibers are fibers which have at least one dimension of 100 nanometer (nm) or less. But in general, the nonwoven industry treats fibers having a diameter of less than one micron as nanofibers" [13]. It has been reported that polymeric nanofibers can also be produced by MB technology through, firstly, changing of processing conditions [18], secondly, by the polymer modification [135 - 137], and finally, by utilizing of special die where orifice diameters, $\mathrm{D}$, are very small $(0.064-0.127 \mathrm{~mm})$ and length to diameter ratio, L/D, is very large $(20 / 1-1,000 / 1)[27,37,69,138]$.

In more detail, Ellison et al. [18] produced average fiber diameter less than $500 \mathrm{~nm}$ for polybutylene terephthalate (PBT), PP and polystyrene (PS) by reduced throughput and increased air flow rate. Nayak et al. [135] produced PP nanowebs (diameter of $438-755 \mathrm{~nm}$ ) by lowering molecular weight of PPs $(100-300 \mathrm{MFI})$ by the injection of air and water at the vent port of the extruder. Recently, Macosko and his team showed that melt blowing immiscible polymer blends containing spherical domains can be used to produce a hierarchical nanofibers-in-microstructure from which nanofibers can be obtained by extraction of the polymer matrix with an appropriate solvent $[96,132,137]$. In more detail, Zuo F. et al. [136] has shown that it is possible to produce PBT and polyethylene-co-chlorotrifluoroethylene (PECTFE) nanofibers, with average diameters as small as $70 \mathrm{~nm}$ from MB fiber-in-fiber polymer blends. Wang Z. et al. [137] prepared nanofibers from water-extractable immiscible polymer blends containing a commercial sulfopolyester (95\%) and poly(butylene terephthalate) (5\%) with average diameter of $66 \mathrm{~nm}$ after washing. Soltani and Macosko [96] produced nanofibers with a record low 
average fiber diameter of $36 \mathrm{~nm}$ (see Figure 7) by islands-in-the-sea method utilizing low viscosity polymers with relatively low surface energy (i.e. having low tendency for coalescence).

$\mathrm{Pu} \mathrm{Y}$. et al. [10] showed that it is possible to reduce the average fiber diameter of polypropylene MB fibers from typical $1.69 \mu \mathrm{m}$ to $960 \mathrm{~nm}$ by using electrostatic-assisted MB process. A special stacked plate die design with an orifice of $0.064 \mathrm{~mm}$ diameter was used to fabricate nanofibres with average diameter of 320 - $470 \mathrm{~nm}$ for a wide range of melt flow index PPs (35 - $1200 \mathrm{MFI}$ [27]. Brang J. et al. [37] fabricated nanofibres (average fiber diameter for most of the fibers less than $500 \mathrm{~nm}$ ) from PP, polyethylene terephthalate (PET), polyamide (PA), polyethylene (PE), polylactic acid (PLA), copolyamides (Co-PA), Perfluorinated elastomer (PFE) by melt blowing using a modified die with plate edge profile having very large length to diameter ratio ( $\mathrm{L} / \mathrm{D}=20 / 1,200 / 1$ or even $1,000 / 1)$ to achieve high web uniformity and small orifice diameters $(\mathrm{D}=0.12 \mathrm{~mm})$. Hassan $\mathrm{M}$. A. et al. [69] manufactured nonwoven membranes by using three different die designs L/D ratio (30, 50, 200), orifice diameter $(0.3048 \mathrm{~mm}, 0.1778 \mathrm{~mm}, 0.127 \mathrm{~mm})$ and hole density $(14,30,39$ holes/cm). Nanofibers which were produced by these three dies have an average fiber size in the range of $300-500 \mathrm{~nm}$. Hills Inc. (West Melbourne) produced MB nanowebs from low viscosity homopolymers (1500 - 1800 MFI) with average diameter of $250 \mathrm{~nm}$ and a range between 25 and $400 \mathrm{~nm}$. According to Hills, apart from the low viscosity, smaller diameter orifices, high spin hole density (100 holes per inch) and extremely high length to diameter ratios enable the production of these nanofibers at reasonable rates, and put MB production in the same size range that was previously the exclusive domain of electrospinning technology [136, $138-140]$.

Table 6 summarizes reported polymeric nanofibers produced via meltblown technology sorted according to mean fiber diameter. 


\section{FLOW INSTABILITIES AND DEFECTS IN MELTBLOWN TECHNOLOGY}

There is a number of flow instabilities and defects which can limit the processing window for the MB technology, especially with respect to smallest achievable fibers, namely:

- "Whipping" (fiber vibration)

- "Die drool"

- "Fiber breakup"

- "Melt spraying"

- "Flies"

- "Generation of small isolated spherical particles"

- "Shots"

- “Jam"

- "Nonuniform fiber diameters"

These flow instabilities are introduced below in more details.

Whipping - bending instability of thin liquid jets in air caused by large levels of melt/air inertia [18, 19, 22, 24, 66, 75, 79, 141 - 149]. Fiber whipping which was previously named fiber vibration, was firstly discovered in MB process by Shambaugh and coworkers [19, 141]. Whipping in MB process is an aerodynamics-driven bending instability [146]. Entov and Yarin were first who developed and described the theory of aerodynamically driven bending instability of thin liquid jets in air [144, 147]. The high velocity of the air is connected with this bending instability [66]. Higher air speeds lead to thinner jets and faster production rates, but also cause the fiber to undergo violent whipping motions. 
It is a possibility that whipping (and its associated defects) could be reduced by applying an air velocity field whose spreading character is minimized. Shambaugh and his coworkers [19, 47, 49] built onedimensional (1D), two-dimensional (2D) and three-dimensional (3D) models successively to predict the fiber diameter in melt blowing. Sun et al. [145] built Euler-Lagrange model to simulate the fiber whipping during melt blowing by regarding the fiber as beads. Later Han et al. [142] as well as Xie et al. [150] used Euler-Lagrange or improved Lagrange approach for simulating fiber whipping in melt blowing. A model called quasi-one-dimensional model presented by Yarin et al. [151] was used for predicting the fiber lay-down patterns on the collector and Battocchio and Sutcliffe [152] also presented a numerical model to describe the fiber dynamics [88]. Xie S. et al. discovered connection between the turbulent air flow field and fluctuating velocity and temperature, which contribute significantly to poor evenness of fiber diameters produced by MB process [24]. Chung C. et al. [147] observed that annular (rather than 2D) air flows lead to a reduction in fiber distortions and as well as Xie S. et al. [153] suggested that melt inertia rather than melt rheology is the more dominant factor in controlling fiber shape.

Whipping can exist in two different forms [22, 154]:

Two-dimensional bending motion, which is connected with slot-die (see Figure 8) where frequency and amplitude of fiber vibration can be changed in this trends:

- frequency decreases as distance from the die head increases,

- frequency decreases as polymer flow rate and temperature increase or if air flow rate decreases,

- air temperature change does not have an effect on the frequency,

- the amplitude increases as distance from the die head increases, 
- the amplitude increases when polymer flow rate decreases or if air flow rate increases,

- the amplitude does not appear to change if either air temperature or polymer temperature are changed.

$>$ Three-dimensional spiral path of fiber in post die area is connected with swirl-die (see Figure 9, middle and right):

- the frequency remains constant as distance from die head increases,

- the amplitude remains constant for the given range of processing conditions,

- the frequency decreases when polymer flow rate and temperature increases or if the air flow rate decreases,

- the frequency is not air temperature dependent.

In general, higher amplitude and frequency of the fiber bending instability can lead to the more uniform fiber laydown (higher amplitude leads to higher overlapping of adjacent fibers whereas higher frequency permits increase of the belt speed without losing laydown quality), which gives a better option for the end use of the MB nonwovens [143].

Die drool - spontaneous accumulation of the polymer at the die exit (see Figure 10) in usually degraded or even solidified mass, which restricts flow and/or can frequently breaks away from the die and cause lowering of resulting properties of the extrudate. There is number of factors inducing die drool we have reviewed just recently [156]:

- "Die design: abrupt corners at die lips, "dead corners" inside extrusion die (thermal degradation), high surface energy die wall materials, high surface roughness, short die land length. 
- Polymer material: low molecular weight fractions, multimodal polymers (low molecular weight tail); high elasticity of polymer; linear architecture of macromolecules; high content of fillers; high concentration/incompatible additives or pigments; high concentration of volatiles; dissimilar material properties in blends; high content of stearates, ester lubricants, extending oils or waxes; chemical reactions between polymer and metal barrel/screw/die.

- Processing conditions: high processing temperature (thermal degradation), draw down, intensive cooling of die exit.

- Other factors: die swell, shark skin, wall slip, vortices (thermal degradation), slip-stick, pressure fluctuations in screw, excessive screw/barrel wear."

\begin{abstract}
Die drool can be eliminated via optimization of extrusion die design, polymer material or processing conditions [156].
\end{abstract}

- "Modification of Extrusion Dies: utilization of low surface energy materials such as wellslipping fluorocarbon polymers, silicon rubber coatings, usage of ceramics dies or hard chrome; usage of chamfered or rounded of the die exit edge, flared die exit, replaceable inserts, dies with short convergent channel followed by long diverging channel.

- Modification of Polymer Materials: addition of processing aids (polytetrafluorethylene, diethylene glycol, polydialkylsiloxane additives); changing molecular structure or composition of extruded polymer (increase in chain branching, decrease in polymer melt elasticity and shear viscosity, addition of antioxidants preventing polymer from degradation); reduction of filler content, optimization of coating agents used to prevent formation of agglomerates; modification of blending of polymers to reduce phase separation during processing. 
- Modification of Processing Conditions: replacement of contaminated air (vaporous and low molecular constituents) in the immediate vicinity of the extrusion orifice by clean hot air or inert gas; reduction in external cooling; reduction of residence time, extreme shearing and viscous dissipation to minimize material degradation"

Fiber breakup - instabilities that are driven by surface tension (for a Newtonian liquid the phenomenon is called Rayleigh instability) - surface tension forces cause fiber necking at different locations leading to pinch off the fiber (note that for viscoelastic melts, extensional stress build-up due to drawing of the fiber can delay or even retard this instability [18] (see Figure 11). The level of entanglement in MB can affect creation of fiber breakup during the fabrication process [18]. Ziabicki (1976) described, that fiber break up is caused by cohesive fracture and/or capillary action [19]. Ellison C. et al. as well as Ruamsuk R. et al. observed that extent of fiber breakup is dependent on both processing temperature and polymer and air flow rates $[18,75]$. Bresee R. suggested less fiber breakage to occur when primary air pressure is decreased and die to collector distance is increased [158]. Han W. et al. has found that polymer melt viscosity plays an important role in the fiber breakup and is affected by air temperature and pressure (i.e. that higher melt viscosity or lower air pressure could reduce the fiber breakup). It has also been observed that the polymer surface tension can increase dramatically with decreasing fiber diameter $[96,157]$.

Melt spraying - significant fiber breakup [18, 144, 147, 159], see Figure 12.

Flies - creation of very short fine fibers, which contaminate the surroundings, because they do not collect on the collector (see Figure 13). This phenomenon is caused by the extreme and excessive 
blowing conditions that cause fiber breakage (air pressure, die to collector distance, collector speed) [18, 69, 75, 87, 88, 148, 149, 158, 160]. Hassan M. et al. [69], Tan D. et al. [161] and Moore E. et al. [51] have found that very high air velocities (supersonic flow) produce unstable air flow field which is responsible for a large quantity unbound fibers (flies). Fly particles can reach almost $150 \mathrm{~m}$ of fiber length [158]. Bresee R. and Qureshi U. [158] published that: "Fly formation is controlled primarily by aerodynamic drag and fiber entanglement". That is to say:" Fly particles are released when a drag force is strong enough to break fibers and fiber entanglement is insufficient to retain broken fibers within the forming web" [158]. Presumably only two regions of the MB process produce enough a large drag force on fiber which leads to generation of fly particles. These regions are characterized by large differences between air and fiber speed and they are located near the die and near the collector.

Generation of small isolated spherical particles - it is supposed that the creation of the spheres is connected with fiber breakup instabilities [18]. Such small spherical particles are intermingled amongst the fibers (see Figure 14) and some of them are able to escape from the produced mats during their collection.

Shots - creation of small (usually degraded) round clumps of polymer in the web that have ill-defined shape (see Figure 15). These shots are a result of extrusion die cleanliness as well as process conditions for example: high temperature, too low polymer molecular weight, or poor equipment cleanliness. Shots are generally attributed to the breakage of the fibers as they are being drawn in the air stream [3, $4,18,75,89,148,149,163,164,165]$. Butin with Lohkamp (1973) suggested that shot is created from elastic "snap back" when fiber broke [165]. However, Milligan and Haynes [166] "never observed a broken fiber except in the case of a plugged and/or chugging orifice" [167] suggesting that a filament 
fracture-snap back model is not adequate. Milligan and Utsman (based on their detailed experimental study) have suggested so called "Filament fusion model" for shot formation which was confirmed by Wallen et al. [168] via evaluation of fiber orientation at the die exit via small angle light scattering. According to this model, the shots formation is caused by the multiple "touching and fusion of the molten fibers near the die" [167, 168], see Figure 16. Milligan and Utsman [167] found that shot intensity increases with increased throughput, extrusion temperature and decreased air velocity. Khan revealed that shot instability becomes more pronounced if the orifice diameter increases [62]. Bresee and Yan [165] conducted an another extensive experimental study related to shot and they formulated following key conclusions.

- Typical shape of shot particles is approximately circular and those visible to human eye are mostly well crystallized (containing large spherulites) with diameter in the range of 100$300 \mu \mathrm{m}$.

- The amount of web area containing shot is typically $<0.1 \%$.

- Shot particles causes melting of nearby fibers.

- "The number of shot particles per unit basis weight decreases with increasing basis weight when basis weight is varied only by changing the collector speed."

- "The number of shot particles per unit web area decreases with increasing die-to collector distance."

- More shot particles are located on the collector side of lower basis weight webs, but more shot particles are located on the other side of heavier basis weight webs when basis weight is varied only by changing the collector speed. 
Bresee and Yan [165] have tried to explain their experimental data in view of three different models. "The Fiber-transformation model”, which "involves first forming fibers and then subsequently transforming them into shot particles" was able to plausible explain only a few experimental observations. "The direct-shot-formation model", which "involves producing shot particles directly at the die without undergoing a fiber-to-shot transformation" was capable qualitatively explain many experimental observations. "The shot-precursor model", which "involves forming shot precursors at the die and allowing these precursors to grow into shot" was able to explain the experimental observations the best. It is believed that "it is likely that shot formation in many webs occurs by a combination of the three models or by some unknown and more complex way than is currently understood".

Jam - fibers accumulation in space due to adhesion between fiber segments (see Figure 17) occurring during fiber speed decrease through the majority of the die to collector distance, which contributes to fiber disorientation and creation of entanglements between the fibers [14, 18, 147]. It was concluded that increase in DCD or decrease in air flow rate leads to more entanglements due to more time for fiber contact/entanglement/fusion $[82,83,158]$. On the other hand, opposite trend was reported by Lee \& Wadsworth (1990) [55] and Yesil \& Bhat (2016) [76], i.e. that an increase in air flow rate or decrease in DCD promotes the fiber entanglements. Thus, it seems that not only the fiber traveling time is important but also actual melt temperature, heat transfer and cooling efficiency of the process plays important role here.

Effect of basic processing variables (such as air speed, polymer flow rate, temperature, DCD and collector speed) on all above described flow instabilities/defects is summarized in Table 7. 
Nonuniform fiber diameters - it has been discovered that fiber diameter distribution for MB nonwovens can be well described by a log-normal distribution function regardless of average fiber diameter [23] (see Figure 18). Tan et al. [23] found for PS that increase in melt viscosity leads to an increase in average fiber diameter with almost no effect on coefficient of variation (CV) whereas increase in the melt elasticity (captured via the longest melt relaxation time, $\lambda$ ) above a threshold value reduces CV but simultaneously increases an average fiber diameter. Drabek and Zatloukal [16] have shown that addition of small amount of high molecular weight long chain branched (LCB) PP into linear isotactic PP can decrease $\mathrm{CV}$ at the same average fiber diameter. It has been suggested that high stability of LCB-PP blend can be explained by its higher stretchability at very high deformation rates (occurring at the die exit where an intensive fiber attenuation takes the place) and its lower stretchability at medium and low deformation rates, at which melt/air inertia driven bending instability called whipping occurs. Deng N. et al. [9] showed that utilization of the incompatible blend system (namely mixture of PP and PS) can increase fiber diameter variation considerably due to continues fluctuation of blend viscosity during MB process as visible in Figure 19. Creation of even helical microfibers with a three- dimensional spiral shape from polypropylene (PP)/thermoplastic polyurethane (TPU) incompatible blend was also reported [169] (see Figure 20).

\section{CONCLUSION}

In the first part of this review paper, a short historical overview about meltblown technology, die design development, polymers used as well as the effect of processing conditions (such as throughput rate, melt rheology, melt temperature, die temperature, air temperature/velocity/pressure and die-to-collector distance) on the basic characteristics of produced nonwovens (such as for example average fiber diameter, fiber entanglement, pore structure, mean pore size, air permeability, tenacity, 
elongation at break) has been summarized. In the second part, specific attention was paid to review the current state of knowledge in area of meltblown technology for production of polymeric nanofibers and typical meltblown instabilities such as whipping, die drool, fiber breakup, melt spraying, flies, generation of small isolated spherical particles, shots, jam and generation of nonuniform fiber diameters.

Even if there is number of useful findings and conclusions, it seems that current fundamental understanding of high deformation rate dynamics of polymer melts as well as related flow stability is still rather limited due to absence of relevant experimental data and methodologies allowing to reveal key structure-rheology-process relations. There is only one report in the open literature on the extensional viscosity measurements at very high extensional strain rates $\left(\sim 10^{6} \mathrm{~s}^{-1}\right)$ for linear and branched PP melts with connection to meltblown process. Obtained results suggest that specific type of chain branching can lower extensional viscosity at extremely high deformation rates, which can stabilize the flow considerably. This opens number of questions. For example, what is the role of the chemical structure of the chain, molecular weight distribution, branching, bulky side groups, coil size/shape on the slip, monomeric friction coefficient and the flow stability at very high deformation rates? In what way the current constitutive equations should be modified to capture polymer melt flow behavior at very high strain rates correctly? What experimental methodology should be applied for given polymer melt to ensure that the measured viscosity data can really be considered as the true material property within the whole applied deformation rate range? Thus, utilization of polymers with well-defined molecular structure together with advanced flow visualization techniques and rheological methodologies allowing both, precise determination of the flow field at the die exit as well as shear and extensional rheology at very high deformation rates, can be considered as the key step to further explore 
understanding of polymeric micro/nano fibers formation by the melt blown technology.

\section{Acknowledgments}

The authors would like to acknowledge the financial support from the Institutional Support Project 2019 (Polymer Centre at Faculty of Technology, Tomas Bata University in Zlín) as well as Grant Agency of the Czech Republic (Grant registration No. 16-05886S). 


\section{REFERENCES}

[1] DUTTON, K. C., Overview and analysis of the meltblown process and parameters. Journal of Textile and Apparel, Technology and Management. 2009, vol. 6, no. 1.

[2] McCULLOCH, J. G., The history of the development of melt blowing technology. International Nonwovens Journal. 1999, vol. 8, no. 1, p. 139 - 149.

SHAMBAUGH, R. L., A macroscopic view of the melt-blowing process for producing microfibers. Industrials and Engineering Chemistry Research. 1988, vol. 27, no. 12, p. 2363 2372.

[4] GAHAN, R. and G. C. ZGURIS, A review of the melt blown process. Proceeding of the Annual Battery Conference on Applications and Advances. 2000, vol. 2000, p. 145 - 149.

[5] ZHAO, R., Melt blown dies: a hot innovation spot. International Nonwovens Journal. 2002, vol. 11 , no. 4 , p. $37-41$.

[6] Scopus services. SciVerse: Open to accelerate science [online]. URL: < https://www.scopus.com/home.uri> [cit. $2019-17-6$ ]

[7] WANG, X. and Q. KE, Experimental investigation of adhesive meltblown web production using accessory air. Polymer Engineering and Science. 2006, vol. 46, no. 1, p. 1 - 7.

[8] NAYAK, R., Fabrication and characterization of polypropylene nanofibers by melt electrospinning and meltblowing. Ph.D. Thesis. RMIT University, Australia, 2012. DENG, N., H. HE, J. YAN, Y. ZHAO, E. BEN TICHA, Y. LIU, W. KANG and B. CHENG, One-step melt-blowing of multi-scale micro/nano fabric membrane for advanced air-filtration. Polymer. 2019, vol. 165, p. $174-179$. 
[10] PU, Y., J. ZHENG, F. CHEN, Y. LONG, H. WU, Q. LI, S. YU, X. WANG and X. NING, Preparation of polypropylene micro and nanofibers by electrostatic-assisted melt blown and their application. Polymers. 2018, vol. 10, Article number 959.

[11] HAN, W., S. XIE, J. SHI and X. WANG, Study on airflow field and fiber motion with new melt blowing die. Polymer Engineering and Science. 2019, vol. 59, p. 1182 - 1189.

[12] HUTTEN, I. M., Processes for Nonwoven Filter Media. In: Handbook of Nonwoven Filter Media, Second Edition, Butterworth-Heinemann. Kidlington, UK, 2015, 276-342. ISBN 9780-08-098301-1

[13]

KARTHIK, T., C. PRABHA KARAN, R. RATHINAMOORTHY, Non-woven: Process, Structure, Properties and Applications, Woodhead Publishing India in Textiles. CRC Press, 2016, p. 358. ISBN 978-9385059124

[14] BRESEE, R. R. and W. KO., Fiber formation during melt blowing. International Nonwovens Journal. 2003, vol. 12, no. 2, p. $21-28$.

[15] DE ROVERE, A., R. L. SHAMBAUGH and E. A. O'REAR, Investigation of gravity-spun, melt-spun, and melt-blown polypropylene fibers using atomic force microscopy. Journal of Applied Polymer Science. 2000, vol. 77, no. 9, p. 1921 - 1937.

[16] DRABEK, J. and M. ZATLOUKAL, Influence of long chain branching on fiber diameter distribution for polypropylene nonwovens produced by melt blown process. Journal of Rheology. 2019, vol. 63, no. 4, p. $519-532$.

[17] XIN, S. and X. WANG, Shear flow of molten polymer in melt blowing. Polymer Engineering and Science. 2012, vol. 52, no. 6, p. 1325 - 1331. 
blown nanofibers: fiber diameter distributions and onset of fiber breakup. Polymer. 2007, vol. 48, no. 11, p. $3306-3316$.

[19] RAO, R. S. and R. L. SHAMBAUGH, Vibration and stability in the melt blowing process. Industrial and Engineering Chemistry Research. 1993, vol. 32, no. 12, p. 3100 - 3111.

[20] CHEN, T., C. ZHANG, X. CHEN and Q. LI, Numerical computation of the fiber diameter of melt blown nonwovens produced by the inset die. Journal of Applied Polymer Science. 2009, vol. 111 , no. 4 , p. $1775-1779$.

[21] XIE, S. and Y. C. ZENG, A geometry method for calculating the fiber diameter reduction in melt blowing. Advanced Materials Research. 2014, vol. 893, p. 87 - 90.

[22] XIE, S., Y. ZHENG, and Y. ZENG, Influence of die geometry on fiber motion and fiber attenuation in the melt-blowing process. Industrial and Engineering Chemistry Research. 2014, vol. 53, no. 32 , p. $12866-12871$.

[23] TAN, D. H., C. ZHOU, C. J. ELLISON, S. KUMAR, C. W. MACOSKO and F. S. BATES, Meltblown fibers: influence of viscosity and elasticity on diameter distribution. Journal of Non-Newtonian Fluid Mechanics. 2010, vol. 165, no. 15-16, p. 892 - 900.

[24] XIE, S., W. HAN, G. JIANG and C. CHEN, Turbulent air flow field in slot-die melt blowing for manufacturing microfibrous nonwoven materials. Journal of Materials Science. 2018, vol. 53, no. 9 , p. $6991-7003$.

[25] SHAMBAUGH, B. R., D. V. PAPAVASSILIOU and R. L. SHAMBAUGH, Modifying air fields to improve melt blowing. Industrial and Engineering Chemistry Research. 2012, vol. 51 , no. 8 , p. $3472-3482$. 
in the melt blowing of nonwovens from isotactic polypropylene by computer modeling, Journal of Applied Polymer Science. 2011, vol. 119, no. 1, p. 53 - 65.

[27]

WARD, G. F., Meltblown nanofibers for nonwoven filtration applications. Filtration and Separation. 2001, vol. 38 , no. 9 , p. $42-43$.

[28] Google Patents [online]. [viewed 2019 - 17 - 6]. Available from: https://patents.google.com/

[29] LOHKAMP, D. and J. KELLER, Melt-blowing die using capillary tubes, US Patent US3825379-A, 1974.

[30] HARDING, J., J. KELLER and R. BUTIN, Melt-blowing die for producing nonwoven mats, US Patent US-3825380-A, 1974.

[31] ECKHARD, C. and A. SCHWARZ, Apparatus and process for melt-blowing a fiber forming thermoplastic polymer and product produced thereby, US Patent US-4380570-A, 1983.

[32] APPEL, D. W., A. D. DROST and J. C. LAU, Slotted melt-blown die head, US Patent US4720252-A, 1988.

[33] BUEHNING, P. G., Melt blowing die, US Patent US-4986743-A, 1991.

[34] ALLEN, M. A. and J. T. FETCKO, Modular meltblowing die, US Patent US-5618566-A, 1997.

[35] MILLIGAN, M. W., Multihole meltblown die nosepiece, US Patent US-6099282-A, 2000.

[36] HAYNES, B. D. and M. CH. COOK, Die for producing meltblown multicomponent fibers and meltblown nonwoven fabrics, US Patent US-7150616-B2, 2006.

[37] BRANG, J., A. WILKIE and J. HAGGARD, Method and apparatus for production of meltblown nanofibers, US Patent US-2008023888-A1, 2008. 
[38] ALLEN, M. A., Melt blowing die, apparatus and method, US Patent US-2017067184-A1, 2017.

[39] ADACHI, H. and Y. MIURA, Melt-blowing die, JP Patent JP-2017203233-A, 2017.

[40] CHEN, T. and X. HUANG, Modeling polymer air drawing in the melt blowing nonwoven process, Textile Research Journal. 2003, vol. 73, no. 7, p. $651-654$.

[41] CHEN, T. and X. HUANG, Air drawing of polymers in the melt blowing nonwoven process: mathematical modeling. Modeling And Simulation In Materials Science and Engineering. 2004, vol. 12 , no. 3 , p. $381-388$.

[42] CHEN, T., X., WANG and X. HUANG, Modeling the air-jet flow field of a dual slot die in the melt blowing nonwoven process, Textile Research Journal. 2004, vol. 74, no. 11, p. 1018 $-1024$.

[43] CHEN, T., L., LI and X. HUANG, Fiber diameter of polybutylene terephthalate melt-blown nonwovens. Journal of Applied Polymer Science. 2005, vol. 97, p. 1750 - 1752.

[44] CHEN, T., X., WANG and X. HUANG, Effects of processing parameters on the fiber diameter of melt blown nonwoven fabrics. Textiles Research Journal. 2005, vol. 75, no. 1, p. $76-80$.

[45] WU, L. L., D. H., HUANG and T. CHEN, Modeling the nanofiber fabrication with the melt blowing annular die, Revista Matéria. 2014, vol. 19, no. 4, p. 377 - 381.

[46] KAYSER, J. C. and R. L. SHAMBAUGH, The manufacture of continuous polymeric filaments by the melt-blowing process. Polymer Engineering and Science. 1990, vol. 30, no. 19, p. $1237-1251$. 
UYTTENDAELE, M. A. J. and R. L. SHAMBAUGH, Melt blowing: General equation development and experimental verification. American Institute of Chemical Engineers Journal. 1990, vol. 36, no. 2, p. 175 - 186.

[48] TYAGI, M. K. and R. L. SHAMBAUGH, Use of oscillating gas jets in fiber processing. Industrial and Engineering Chemistry Research. 1995, vol. 34, p. 656 - 660.

[49] MARLA, V. T. and R. L. SHAMBAUGH, Three-Dimensional model of the melt-blowing process, Industrial and Engineering Chemistry Research. 2003, vol. 42, no. 26, p. 6993 7005.

[50] MARLA, V. T. and R. L. SHAMBAUGH, Modeling of the melt blowing performance of slot die, Industrial and Engineering Chemistry Research. 2004, vol. 43, no. 11, p. 2789 - 2797.

[51] MOORE, E. M., D. V., PAPAVASSILIOU and R. L. SHAMBAUGH, Air velocity, air temperature, fiber vibration and fiber diameter measurements on a practical melt blowing die. International Nonwovens Journal. 2004, vol. 13, no. 3, p. 43 - 53.

[52] SHAMBAUGH, B. R., D. V. PAPAVASSILIOU and R. L. SHAMBAUGH, Next-generation modeling of melt blowing, Industrial and Engineering Chemistry Research. 2011, vol. 50, p. $12233-12245$.

WADSWORTH, L. C. and A. M. JONES, Novel melt blown research findings. The International Nonwovens Technical Conference. Philadelphia, USA, 1986, code 11191.

[54] CHOI, K. J., J. E. SPRUIELL, J. F. FELLERS and L. C. WADSWORTH, Strength properties of melt blown nonwoven webs, Polymer Engineering and Science. 1988, vol. 28, no. 2, p. 81 $-89$.

[55] LEE, Y. and L. C. WADSWORTH, Structure and filtration properties of melt blown polypropylene webs, Polymer Engineering and Science. 1990, vol. 30, no. 22, p. 1413 - 1419. 
MILLIGAN, M. W., F. LU, R. R. BUNTIN and L. C. WADSWORTH, The use of crossflow to improve nonwoven melt-blown fibers, Journal of Applied Polymer Science. 1992, vol. 44, p. $279-288$.

SUN, Q., D. ZHANG, B. CHEN and L. C. WADSWORTH, Application of neural network to meltblown process control, Journal of Applied Polymer Science. 1996, vol. 62, p. 1605 1611.

[58] WENTE, V. A., E. L. BOONE and C. D. FLUHARTY, Manufacture of superfine organics fibers, (NRL Report 4364), 1954, Washington, D. C.: Naval Research Laboratory.

[59] MALKAN, S. R., Process-structure-property relationships in different molecular weight polypropylene melt-blown webs, Ph.D Thesis. The University of Tennessee, Knoxville, USA, 1990.

[60] HAYES, B. D., An experimental and analytical investigation on the production of microfibers using a single-hole melt blowing process, Ph.D Thesis. The University of Tennessee, Knoxville, USA, 1991.

[61] STRAEFFER, G. and B. C. GOSWAMI, Mechanical and structural properties of melt-blown fibers. In J. E. Riedel (Ed.), Principles of nonwovens, 1992, Cary, NC: INDA, p. 479 - 513.

KHAN, A. Y. A., A fundamental investigation of the effects of die geometry and process variables on fiber diameter and quality of melt blown polypropylene webs, Ph.D Thesis. The University of Tennessee, Knoxville, USA, 1993.

[63] ZHANG, D., C., SUN, J. BEARD, H. BROWN, I. CARSON and C. HWO, Development and characterization of poly(trimethylene terephthalate)- based bicomponents meltblown nonwovens, Journal of Applied Polymer Science. 2002, vol. 83, p. 1280 - 1287. 
[64] BRESEE, R. R. and U. A. QURESHI, Influence of process conditions on melt blown web structure: Part IV - fiber diameter. Journal of Engineered Fibers and Fabrics. 2006, vol. 1, no. 1, p. $32-46$.

[65]

DURAN, D. and S. PERINCEK, The effect of various production parameters on the physical properties of polypropylene meltblown nonwovens. Industria Textila. 2010, vol. 61, no. 3, p. $117-123$.

[66] ZENG, Y. C., Y. F. SUN and X. H. WANG, Numerical approach to modeling fiber motion during melt blowing, Journal of Applied Polymer Science. 2011, vol. 119, no. 4, p. 2112 2123.

[67]

DURAN, K., D. DURAN, G. OYMAK, K. KILIÇ, E. ÖNCÜ and M. KARA, Investigation of the physical properties of meltblown nonwovens for air filtration, Tekstil ve Konfeksiyon. 2013, vol. 23 , no. 2 , p. $136-142$.

[68] HAN, W., X. WANG and G. S. BHAT, Structure and air permeability of melt blown nanofiber webs, Journal of Nanomaterials \& Molecular Nanotechnology. 2013, vol. 2, no. 3.

[69] HASSAN, M. A., B. Y. YEOM, A. WILKIE, B. POURDEYHIMI and S. A. KHAN, Fabrication of nanofiber meltblown membranes and their filtration properties. Journal of Membrane Science. 2013, vol. 427, p. 336 - 344.

[70] WANG, Y. and X. WANG, Investigation on a New Annular Melt-Blowing die using numerical simulation, Industrial and Engineering Chemistry Research. 2013, vol. 52, no. 12, p. $4597-4605$.

[71] NAYAK, R., I. L. KYRATZIS, Y. B. TRUONG, R. PADHYE and L. ARNOLD, Structural and mechanical properties of polypropylene nanofibres fabricated by meltblowing, Journal of the Textile Institute. 2015, vol. 106, no. 6, p. $629-640$. 
[72] ZHAO, B., Numerical modeling and experimental investigation of fiber diameter of melt blowing nonwoven web, International Journal of Clothing Science and Technology. 2015, vol. 27 , no. 1 , p. $91-98$.

[73] GUO, M., H. LIANG, Z. LUO, Q. CHEN and W. WEI, Study on melt-blown processing, web structure of polypropylene nonwovens and its BTX adsorption, Fibers and Polymers. 2016, vol. 17 , no. 2 , p. $257-265$.

[74] RENUKARN, R., W. TAKARADA and T. KIKUTANI, Melt-blowing conditions for preparing webs consisting of fine fibers, AIP Conference Proceedings. 2016, vol. 1779, art. n. 120002.

[75] RUAMSUK, R., W. TAKARADA, T. KIKUTANI, Fine filament formation behavior of polymethylpentene and polypropylene near spinneret in melt blowing process, International Polymer Processing. 2016, vol. 31, no. 2, p. 217 - 223.

[76] YESIL, Y. and G. S. BHAT, Structure and mechanical properties of polyethylene melt blown nonwovens, International Journal of Clothing Science and Technology. 2016, vol. 28, no. 6, p. $780-793$.

[77] FENG, J., Preparation and properties of poly(lactic acid) fiber melt blown non-woven disordered mats, Materials Letters. 2017, vol. 189, p. 180 - 183.

[78] SUN, G. W., J. SONG, L. XU, H. WANG, Numerical modelling of microfibers formation and motion during melt blowing, Journal of the Textile Institute. 2018, vol. 109, no. 3, p. $300-$ 306.

[79] HAO, X., H. HUANG, Y. ZENG, Simulation of jet velocity in the melt-blowing process using the coupled air-polymer model, Textile Research Journal. 2018, vol. 89, no. 16, p. 3221 $-3233$. 
[80] WU, T. T. and R. L. SHAMBAUGH, Characterization of the melt blowing process with laser Doppler velocimetry, Industrial and Engineering Chemistry Research.1992, vol. 31, p. 379 389.

[81] QURESHI, U. A., Understanding the role of the collector during melt blowing, Master Thesis. The University of Tennessee, Knoxville, USA, 2001.

BRESEE, R. R. and U. A. QURESHI, Influence of processing conditions on melt blown web structure: Part 1 - DCD, International Nonwovens Journal. 2004, vol. 13, no. 1, p. 49 - 55.

BRESEE, R. R., U. A. QURESHI and M. C. PELHAM, Influence of processing conditions on melt blown web structure: Part 2 - Primary airflow rate, International Nonwovens Journal. 2005, vol. 14 , no. 2 , p. $11-18$.

[84]

ZAPLETALOVA, T., S. MICHIELSEN and B. POURDEYHIMI, Polyether based thermoplastic polyurethane melt blown nonwovens, Journal of Engineered Fibers and Fabrics. 2006, vol. 1 , no. 1 , p. $62-72$.

UPPAL, R., G. BHAT, C. EASH and K. AKATO, Meltblown nanofiber media for enhanced quality factor, Fibers and Polymers. 2013, vol. 14, no. 4, p. $660-668$.

GHOSAL, A., S. SINHA-RAY, L. A. YARIN and B. POURDEYHIMI, Numerical prediction of the effect of uptake velocity on three-dimensional structure, porosity and permeability of meltblown nonwoven laydown, Polymer (United Kingdom). 2016, vol. 85, p. 19 - 27. SUN, G., X. SUN, X. WANG, Study on uniformity of a melt-blown fibrous web based on an image analysis technique, e-Polymers. 2017, vol. 17, no. 3, p. $211-214$. SUN, G., J. YANG, S. XIN, R. YU, X. WANG, Influence of processing conditions on the basis weight uniformity of Melt-Blown fibrous webs: numerical and experimental study, Industrial and Engineering Chemistry Research. 2018, vol. 57, p. 9707 - 9715. 
[89] BHAT, G. S. and S. R. MALKAN, Polymer-laid web formation. In: Handbook of nonwovens, RUSSELL S. J., Woodhead publishing in textiles. Cambridge, England: CRC Press, 2007, p. 143-195. ISBN 978-1-85573-603-0

[90] MALKAN, S. and L. Wadsworth, Polymer-laid systems. In: Nonwovens: Theory, Process, Performance and Testing, TURBAK A. F., TAPPI PRESS. Atlanta, Georgia, 1993, p. 171 192. ISBN 978-0898522655

[91] VAN KREVELEN, D. W. and K. TE NIJENHUIS, Properties of Polymers: Their correlation with chemical structure; Their numerical estimation and prediction from additive group contributions $4^{\text {th }}$ Edition. Oxford, UK, Elsevier Science, 2009, p. 1 - 1030, ISBN 9780080548197

[92] KUCUKALI OZTURK, M., M. VENKATARAMAN and R. MISHRA, Influence of structural parameters on thermal performance of polypropylene nonwovens. Polymers for Advanced Technologies. 2018, vol. 29, no. 12, p. 3027 - 3034.

[93] WALCZAK, J., M. CHRZANOWSKI and I. KRUCIŃSKA, Research on a nonwoven fabric made from multi-block biodegradable copolymer based on L-Lactide, Glycolide, and Trimethylene Carbonate with shape memory. Molecules. 2017, vol. 22, no. 8, article number 1325.

[94] ELLIS, B. and R. SMITH, Polymers: A Property Database $2^{\text {nd }}$ Edition. Boca Raton, FL. CRC Press, 2008, p. 118. ISBN 978-0849339400

[95] MARK, J.E., Physical Properties of Polymers Handbook $2^{\text {nd }}$ Edition. New York, Springer, 2007, p. 1-1076, ISBN 9780387312354 
[96] SOLTANI, I. and C. W. MACOSKO, Influence of rheology and surface properties on morphology of nanofibers derived from islands-in-the-sea meltblown nonwovens. Polymer (United Kingdom). 2018, vol. 145, p. $21-30$.

[97] KAREEM, S. A., Meltblown web technology: process and applications. Journal of Engineering Applications. 2000, vol. 2, no. 1, p. $24-34$.

[98] KEENE, B., M. BOURHAM, V. VISWANATH, H. AVCI and R. KOTEK, Characterization of degradation of polypropylene nonwovens irradiated by $\gamma$-ray. Journal of Applied Polymer Science. 2014, vol. 131, no. 4, article number 39917.

[99] ZHANG, H., J. LIU, X. ZHANG, C. HUANG and X. JIN, Design of electret polypropylene melt blown air filtration material containing nucleating agent for effective PM2.5 capture. RSC Advances. 2018, vol. 8, no. 15, p. 7932 - 7941.

[100] KILIC, A., E. SHIM and B. POURDEYHIMI, Electrostatic capture efficiency enhancement of polypropylene electret filters with barium titanate. Aerosol Science and Technology. 2015, vol. 49 , no. 8 , p. $666-673$.

[101] BROCHOCKA, A., K. MAJCHRZYCKA and K. MAKOWSKI, Modified melt-blown nonwovens for respiratory protective devices against nanoparticles. Fibres and Textiles in Eastern Europe. 2013, vol. 100, no. 4, p. 106 - 111.

[102] XIAO, H., J. GUI, G. CHEN and C. XIAO, Study on correlation of filtration performance and charge behavior and crystalline structure for melt-blown polypropylene electret fabrics. Journal of Applied Polymer Science. 2015, vol. 132, no. 47, article number 42807.

[103] HIEMENZ, P. C. and T. P. LODGE, Polymer chemistry, $2^{\text {nd }}$ ed., Taylor \& Francis Group, Florida, Boca Raton: CRC Press, 2007, p. 608. ISBN 978-1574447798 
[104] CHEN, X., M. A. DAM, K. ONO, H. SHEN, S. R. NUTT, K. SHERAN and F. WUDL, A thermally re-mendable cross-linked polymeric material. Science. 2002, vol. 295, no. 5560, p. $1698-1702$.

[105] MONTGOMERY, S. J., G. KANNAN, E. GALPERIN and S. D. KIM, Thermally stable UV crosslinkable copolyesters: Synthesis, crosslinking, and characterization of poly(1,4cyclohexylenedimethylene - 1,4-cyclohexane dicarboxylate- co -4,4'-stilbene dicarboxylate). Macromolecules. 2010, vol. 43, no. 12, p. 5238 - 5244.

[106] TAN, A. R., J. L. IFKOVITS, B. M. BAKER, D. M. BREY, R. L. MAUCK and J. A. BURDICK, Electrospinning of photocrosslinked and degradable fibrous scaffolds. Journal of Biomedical Material Research - Part A. 2008, vol. 87, no. 4, p. 1034 - 1043.

[107] KIM, S. H., S. -H. KIM, S. NAIR and E. MOORE, Reactive electrospinning of cross-linked poly(2-hydroxyethyl methacrylate) nanofibers and elastic properties of individual hydrogel nanofibers in aqueous solutions. Macromolecules. 2005, vol. 38, no. 9, p. $3719-3723$.

[108] GESTOS, A., P. G. WHITTEN, G. M. SPINKS and G. G. WALLACE, Crosslinking neat ultrathin films and nanofibers of $\mathrm{pH}$-responsive poly(acrylic acid) by UV radiation. Soft Matter. 2010, vol. 6, no. 5, p. $1045-1052$.

[109] QIN, X. -H. AND S. -Y. WANG, Electrospun nanofibers from crosslinked poly(vinyl alcohol) and its filtration efficiency. Journal of Applied Polymer Science. 2008, vol. 109, no. 2, p. $951-956$.

[110] LEE, S., B. KIM, S. -H. KIM, E. KIM and J. -H. JANG, Superhydrophobic, reversibly elastic, moldable, and electrospun (SupREME) fibers with multimodal functions: From oil absorbents to local drug delivery adjuvants. Advanced Functional Materials. 2017, vol. 27, no. 37, article number 1702310 . 
[111] SARKAR, K., C. GOMEZ, S. ZAMBRANO, M. RAMIREZ, E. DE HOYOS, H. VASQUEZ and K. LOZANO, Electrospinning to Forcespinning. Materials Today. 2010, vol. 13, no. 11, p. $12-14$.

[112] WOUTERS, M., E. CRAENMEHR, K. TEMPELAARS, H. FISCHER, N. STROEKS and J. VAN ZANTEN, Preparation and properties of a novel remendable coating concept. Progress in Organic Coatings. 2009, vol. 64, no. 2-3, p. $156-162$.

[113] ADZIMA, B. J., H. A. AGUIRRE, C. J. KLOXIN, T. F. SCOTT and C. N. BOWMAN, Rheological and chemical analysis of reverse gelation in a covalently cross-linked diels-alder polymer network. Macromolecules. 2008, vol. 41, no. 23, p. 9112 - 9117.

[114] IMAI, Y., H. ITOH, K. NAKA and Y. CHUJO, Thermally reversible IPN organic polymer hybrids utilizing the Diels-Alder reaction. Macromolecules. 2000, vol. 33, no. 12, p. 4343 4346.

[115] FROIDEVAUX, V., M. BORNE, E. LABORBE, R. AUVERGNE, A. GANDINI and B. BOUTEVIN, Study of the diels-alder and retro-diels-alder reaction between furan derivatives and maleimide for the creation of new materials. RSC Advances. 2015, vol. 5, no. 47, p. $37742-37754$.

[116] GOITI, E., F. HEATLEY, M. B. HUGLIN and J. M. REGO, Kinetic aspects of the DielsAlder reaction between poly(styrene-co- furfuryl methacrylate) and bismaleimide. European Polymer Journal. 2004, vol. 40, no. 7, p. $1451-1460$.

[117] INOUE, K., M. YAMASHIRO and M. IJI, Recyclable shape-memory polymer: Poly(lactic acid) crosslinked by a thermoreversible diels-alder reaction. Journal of Applied Polymer Science. 2009, vol. 112, no. 2, p. 876-885. 
[118] KLOXIN, C. J. and C. N. BOWMAN, Covalent adaptable networks: Smart, reconfigurable and responsive network systems. Chemical Society Reviews. 2013, vol. 42, no. 17, p. 7161 7173.

[119] DENISSEN, W., J. M. WINNE and F. E. DU PREZ, Vitrimers: Permanent organic networks with glass-like fluidity. Chemical Science. 2016 , vol. 7 , no. 1, p. $30-38$.

[120] SHI, Q., K. YU, X. KUANG, X. MU, C. K. DUNN, M. L. DUNN, T. WANG and H. JERRY QI, Recyclable 3D printing of vitrimer epoxy. Materials Horizons. 2017, vol. 4, no. 4, p. 598 $-607$.

[121] JIN, K., S. -S. KIM, J. XU, F. S. BATES and C. J. ELLISON, Melt-blown cross-linked fibers from thermally reversible Diels-Alder polymer networks. ACS Macro Letters, 2018, vol. 7, no. 11, p. $1339-1345$.

[122] JIN, K., A. BANERJI, D. KITTO, F. S. BATES and C. J. ELLISON, Mechanically robust and recyclable cross-linked fibers from melt blown anthracene-functionalized commodity polymers. ACS Applied Materials and Interfaces. 2019, vol. 11, no. 13, p. 12863 - 12870. DAS, D., A. K. PRADHAN, R. CHATTOPADHYAY and S. N. SINGH, Composite nonwovens. Textile Progress. 2012, vol. 44, no. 1, p. 1 - 84 .

[124] WANG, H., Y. ZHANG, H. GAO, X. JIN and X. XIE, Composite melt-blown nonwoven fabrics with large pore size as Li-on battery separator. International Journal of Hydrogen Energy. 2016, vol. 41, no. 1, p. $324-330$.

[125] ZHAO, J., C. XIAO, N. XU, Evaluation of polypropylene and poly (butylmethacrylate-cohydroxyethylmethacrylate) nonwoven material as oil absorbent. Environmental Science and Pollution Research. 2013, vol. 20, no. 6, p. 4137 - 4145. 
BLAZKOVA, J. HAVLICEK, O. NOVAK, P. MIKES, E. PROSECKA, D. LUKAS and E. KUZELOVA KOSTAKOVA, The combination of meltblown and electrospinning for bone tissue engineering. Materials Letters. 2015, vol. 143, p. $172-176$.

[127] GUTAROWSKA, B. and A. MICHALSKI, Antimicrobial activity of filtrating meltblown nonwoven with the addition of silver ions. Fibres and Textiles in Eastern Europe. 2009, vol. 74 , no. 3 , p. $23-28$.

[128] LIU, Y., B. CHENG, N. WANG, W. KANG, W. ZHANG, K. XING and W. YANG, Development and performance study of polypropylene/polyester bicomponent melt-blowns for filtration. Journal of Applied Polymer Science. 2012, vol. 124, no. 1, p. 296 - 301.

[129] GRAFE, T. and K. GRAHAM, Polymeric nanofibers and nanofiber webs: a new class of nonwovens. International Nonwovens Journal, spring, 2003, DOI: 10.1177/1558925003os1200113.

[130] VISITA, R. and D. S. KATTI, Nanofibers and their applications in tissue engineering, International Journal of Nanomedicine. 2006, vol. 1, no. 1, p. 15 - 30.

[131] KHAJAVI, R., M. ABBASIPOUR and A. BAHADOR, Electrospun biodegradable nanofibers scaffolds for bone tissue engineering, Journal of Applied Polymer Science. 2016, vol. 133, no. 3, article number 42883.

[132] LI, D. and Y. XIA, Electrospinning of nanofibers: Reinventing the wheel?, Advanced Materials. 2004, vol. 16, no. 14, p. $1151-1170$.

[133] HAN, W., S. XIE, X. SUN, X. WANG and Z. YAN, Optimization of airflow field via solution blowing for chitosan/PEO nanofiber formation, Fibers and Polymers. 2017, vol. 18, no. 8 , p. $1554-1560$. 
[134] NAYAK R., Polypropylene Nanofibers: Melt Electrospinning Versus Meltblowing, Springer International Publishing, Cham, Switzerland, 2017, p. 190. ISBN 978-3319614571

[135] NAYAK, R., I. L. KYRATZIS, Y. B. TRUONG, R. PADHYE, L. ARNOLD, G. PEETERS, M. O’SHEA and L. NICHOLS, Fabrication and characterization of polypropylene nanofibres by meltblowing process using different fluids. Journal of Materials Science. 2013, vol. 48, no. 1, p. $273-281$.

[136] ZUO, F., D. H. TAN, Z. WANG, S. JEUNG, C. W. MACOSKO and F. S. BATES, Nanofibers from melt blown fiber-in-fiber polymer blends. ACS Macro Letters. 2013, vol. 2, no. 4 , p. $301-305$.

[137] WANG, Z., X. LIU, C. W. MACOSKO and F. S. BATES, Nanofibers from water-extractable melt-blown immiscible polymer blends. Polymer (United Kingdom). 2016, vol. 101, p. 269 273.

[138] NAYAK, R., R. PADHYE, I. L. KYRATZIS, Y. B. TRUONG and L. ARNOLD, Recent advances in nanofibre fabrication techniques. Textile Research Journal. 2012, vol. 82, no. 2, p. $129-147$.

[139] WILSON, A., The formation of dry, wet, spunlaid and other types of nonwovens. In: Applications of nonwovens in technical textiles, CHAPMAN, R. A., Woodhead publishing series in textiles. Cambridge, England: CRC Press, 2010, 3 - 16. ISBN 978-1-84569-437-1

[140] WILKIE, A. and J. HAGGARD, Nanofiber melt blown nonwovens-A new low. International Fiber Journal. 2007, vol. 22, no. 3, p. 48 - 49.

[141] CHHABRA, R. and R. L. SHAMBAUGH, Experimental measurements of fiber threadline vibrations in the melt-blowing process. Industrial and Engineering Chemistry Research. 1996, vol. 35 , no. 11, p. $4366-4374$. 
[142] HAN, W. and X. WANG, Modeling melt blowing fiber with different polymer constitutive equations. Fibers and Polymers. 2016, vol. 17, no. 1, p. $74-79$.

[143] BEARD, J. H., R. L. SHAMBAUGH, B. R. SHAMBAUGH and D. W. SCHMIDTKE, Online measurement of fiber-motion during melt blowing. Industrial and Engineering Chemistry Research. 2007, vol. 46, no. 22, p. $7340-7352$.

[144] XIE, S. and Y. ZENG, Online measurement of fiber whipping in the melt-blowing process. Industrial and Engineering Chemistry Research. 2013, vol. 52, no. 5, p. 2116 - 2122.

[145] SUN, Y., Y. ZENG and X. WANG, Three-dimensional model of whipping motion in the processing of microfibers. Industrial and Engineering Chemistry Research. 2011, vol. 50, no. 2, p. $1099-1109$.

[146] XIE, S. and Y. ZENG, Turbulent air flow field and fiber whipping motion in the melt blowing process: Experimental study. Industrial and Engineering Chemistry Research. 2012, vol. 51, no. 14 , p. $5346-5352$.

[147] CHUNG, C. and S. KUMAR, Onset of whipping in the melt blowing process. Journal of NonNewtonian Fluid Mechanics. 2013, vol. 192, p. 37 - 47.

[148] SINHA-RAY, S., A. L. YARIN and B. POURDEYHIMI, Meltblowing: I-basic physical mechanisms and threadline model. Journal of Applied Physics. 2010, vol. 108, no. 3, article number 034912 .

[149] YARIN, A. L., SINHA-RAY S. and B. POURDEYHIMI, Meltblowing: II-linear and nonlinear waves on viscoelastic polymer jets. 2010, vol. 108, no. 3, article number 034913.

[150] XIE, S., Y. ZENG, W. HAN and G. JIANG, An improved Lagrangian approach for simulating fiber whipping in slot-die melt blowing. Fibers and Polymers. 2017, vol. 18, no. 3, p. $525-532$. 
[151] YARIN, A. L., S. SINHA-RAY and B. POURDEYHIMI, Meltblowing: Multiple polymer jets and fiber-size distribution and lay-down patterns. Polymer. 2011, vol. 52, no. 13, p. 2929 2938.

[152] BATTOCCHIO, F. and M. P. F. SUTCLIFFE, Modelling fiber laydown and web uniformity in nonwoven fabric. Modelling and Simulation in Materials Science and Engineering. 2017, vol. 25 , no. 3 , article number 035006 .

[153] XIE, S. and Y. ZENG, Fiber spiral motion in a swirl die melt-blowing process. Fibers and Polymers. 2014, vol. 15 , no. 3 , p. $553-559$.

[154] XIE, S., W. HAN and G. JIANG, Three dimensional numerical simulation for air flow field in melt blowing. Journal of Physics: Conference Series. 2017, vol. 916, no. 1, article number 012044.

[155] MUSIL, J. and M. ZATLOUKAL, Experimental investigation of flow induced molecular weight fraction phenomenon for two linear HDPE polymer melts having same Mn and Mw but different Mz and Mz+1 average molecular weights. Chemical Engineering Science. 2012, vol. 81 , p. $146-156$.

[156] MUSIL, J. and M. ZATLOUKAL, Historical review of die drool phenomenon in plastic extrusion. Polymer Reviews. 2014, vol. 54, no. 1, p. 139 - 184.

[157] HAN, W., G. S. BHAT and X. WANG, Investigation of nanofiber breakup in the meltblowing process. Industrial and Engineering Chemistry Research. 2016, vol. 55, no. 11, p. $3150-3156$.

[158] BRESEE, R. R. and U. A. Qureshi, Fiber motion near the collector during melt blowing: part 2 - fly formation. International Nonwovens Journal. 2002, vol. 11, no. 3, p. 21 - 27. 
[159] PINCHUK, L.S., V. A. GOLDADE, A. V. MAKAREVICH and V. N. KESTELMAN, Melt blowing techniques. In: Melt blowing equipment, technology, and polymer fibrous materials, PINCHUK, L. S., V. A. GOLDADE, A. V. MAKAREVICH and V. N. KESTELMAN, Materials processing. New York, USA: Springer, 2002, 5-20, ISBN 3-540-43223-x

[160] VARGAS, E., Meltblown technology Today: an overview of raw materials, processes, products, markets, and emerging end uses. San Francisco, USA: California: Miller Freeman, 1989, 1 - 316, ISBN 9780879301767

[161] TAN, D. H., P. K. HERMAN, F. S. BATES, S. KUMAR and C. W. MACOSKO, Influence of Laval nozzles on the air flow field in melt blowing apparatus. Chemical Engineering Science. 2012, vol. 80, p. $342-348$.

[162] MAJCHRZYCKA, K., M. OKRASA, A. BROCHOCKA and W. URBANIAKDOMAGALA, Influence of low-temperature plasma treatment on the liquid filtration efficiency of melt-blown PP nonwovens in the conditions of simulated use of respiratory protective equipment. Chemical and Process Engineering-Inzynieria Chemiczna I Procesowa. 2017, vol. 38, no. 2, p. $195-207$.

[163] KO, W. C. and R.R. BRESEE, FT-IR microspectroscopic study of shot formation in meltblown webs. Applied Spectroscopy. 2003, vol. 57, no. 6, p. $636-641$.

[164] BRESEE, R. R., Influence of processing conditions on melt blown web structure. Part III water quench. International Nonwovens Journal. 2005, vol. 14, no. 4, p. 27 - 35 .

[165] BRESEE, R. R. and Z. YAN, Shot development in meltblown webs. Journal of the Textile Institute. 1998, vol. 89, no. 2, p. $304-319$.

[166] HAYNES, B. and M. MILLIGAN, Experimental investigation of melt blowing. INDA Journal of Nonwovens Research. 1991, vol. 3, no. 4, p. 20 - 25. 
[167] MILLIGAN, M. W. and F. UTSMAN, An investigation of the meltblown web defect known as shot. International Nonwovens Journal. 1995, vol. 7, no. 2, p. 65 - 68 .

[168] WALLEN, J., J. F. FELLERS and M. W. MILLIGAN, Small angle light scattering studies of fiber orientation and shot formation in the melt blowing process. International Nonwovens Journal. 1995, vol. 7, no. 3, p. $51-54$.

[169] LI, H., H. HUANG, X. MENG and Y. ZENG, Fabrication of helical microfibers from melt blown polymer blends. Journal of Polymer Science, Part B: Polymer Physics. 2018, vol. 56, no. 13 , p. $970-977$. 
Table 1. Summarization of the most important MB die designs in chronological order [5, 27, 28]

\begin{tabular}{|c|c|c|c|c|c|}
\hline $\begin{array}{c}\begin{array}{c}\text { Publication } \\
\text { date }\end{array} \\
\end{array}$ & $\begin{array}{c}\text { Identification } \\
\text { number }\end{array}$ & Title & Inventor/author & Description & $\begin{array}{l}\text { Notation } \\
\text { in Fig. } 4\end{array}$ \\
\hline 23. 7.1974 & US-3825379-A & $\begin{array}{l}\text { Melt-blowing die using } \\
\text { capillary tubes }\end{array}$ & $\begin{array}{l}\text { D. Lohkamp, } \\
\text { J. Keller }\end{array}$ & $\begin{array}{l}\text { The die is a two-piece assembly and capillary tubes are included in the solder layer between the } \\
\text { two pieces to form the die apparatus. Capillary type has the advantages in achieving longer holes } \\
\text { and more precise alignment of the orifice with great ease. }[5,29]\end{array}$ & A \\
\hline 23. 7.1974 & US-3825380-A & $\begin{array}{l}\text { Melt-blowing die for } \\
\text { producing nonwoven mats }\end{array}$ & $\begin{array}{l}\text { J. Harding, } \\
\text { J. Keller, } \\
\text { R. Buntin }\end{array}$ & $\begin{array}{l}\text { Drilled hole type MB die, which usually has a pair of air slots in each side of the nosepiece, that } \\
\text { are connected to the air manifolds and can be adjusted to form different die settings. }[5,30]\end{array}$ & B \\
\hline 19. 4.1983 & US-4380570-A & $\begin{array}{l}\text { Apparatus and process for } \\
\text { melt-blowing a fiber } \\
\text { forming thermoplastic } \\
\text { polymer and product } \\
\text { produced thereby }\end{array}$ & $\begin{array}{l}\text { Eckhard C. A. } \\
\text { Schwarz }\end{array}$ & $\begin{array}{l}\text { Fiber-forming polymer is heated up to low viscosity and accelerated quickly by nozzle blown air } \\
\text { to near sonic velocity to produce fine fibers with little polymer degradation. This discovery broke } \\
\text { the limitation of air from two sides of the tapered die tip. Therefore, a number of orifice rows can } \\
\text { be arrayed in a single die head to achieve desirable productivity without tremendous capital } \\
\text { increase. [5,31] }\end{array}$ & $\mathrm{C}$ \\
\hline 19. 1.1988 & US-4720252-A & Slotted melt-blown die head & $\begin{array}{l}\text { D. W. Appel, } \\
\text { A. D. Drost, } \\
\text { J. C. Lau }\end{array}$ & $\begin{array}{c}\text { The slot die has a single continuous slot opening running its length, instead of a number of } \\
\text { individual orifices. In order to produce fiber instead of film, at least one of the inner sides of the } \\
\text { slot has spaced grooves perpendicular to the apex line and one of the sides extends below the other } \\
\text { side to form a lip within the fluid stream. }[5,32]\end{array}$ & $\mathrm{D}$ \\
\hline 22. 1.1991 & US-4986743-A & Melt blowing die & P. G. Buehning & $\begin{array}{l}\text { The die tip is mounted by bolting inwardly toward the orifices onto the die body. Opposite and } \\
\text { equal forces are applied on both sides of the orifice row to secure the die tip. The mounted die tip } \\
\text { can be then easily disassembled and cleaned by specialty techniques and equipment, such as high } \\
\text { temperature ovens and ultrasonic cleaners. }[5,33]\end{array}$ & E \\
\hline 8. 4. 1997 & US-5618566-A & Modular meltblowing die & $\begin{array}{l}\text { M. A. Allen, } \\
\text { J. T. Fetcko }\end{array}$ & $\begin{array}{l}\text { Modular dies enables the users to vary the length of the die by merely adding modules or } \\
\text { removing modules from structure. Each module consists of a body, a die tip assembly, and } \\
\text { polymer and air flow passages for conducting hot melt and hot air from the manifold through each } \\
\text { module. The cost of modular die tip is approximately } \$ 300 / \text { inch, which is relatively inexpensive } \\
\text { comparing to } \$ 1300 / \text { inch for regular single-row-orifice, single-metal long die tip. [5, 34] }\end{array}$ & $\mathrm{F}$ \\
\hline 8. 8.2000 & US-6099282-A & $\begin{array}{l}\text { Multihole meltblown die } \\
\text { nosepiece }\end{array}$ & M. W. Milligan & $\begin{array}{c}\text { MB die nosepiece comprises a multiplicity of offset holes for hot melt extrusion. In each pair of } \\
\text { adjacent holes, the first hole angled toward the upper face and a second hole angled toward the } \\
\text { lower face. It is claimed that this nosepiece reduces the filament-to-filament interaction, thus } \\
\text { minimizing the "shot" formation. }[5,35]\end{array}$ & G \\
\hline 19. 12. 2006 & US-7150616-B2 & $\begin{array}{l}\text { Die for producing } \\
\text { meltblown multicomponent } \\
\text { fibers and meltblown } \\
\text { nonwoven fabrics }\end{array}$ & $\begin{array}{l}\text { B. D. Haynes, } \\
\text { M. Ch. Cook }\end{array}$ & $\begin{array}{l}\text { A die tip adapted for extruding a plurality of meltblown multicomponent filaments that includes at } \\
\text { least two series of conduits that extend and converge in to the interior of the die tip to convey a } \\
\text { multicomponent thermoplastic structure in to the interior of the die tip to a series of capillaries that } \\
\text { extend to a series of die opening for extruding multicomponent filaments is provided. [36] }\end{array}$ & $\mathrm{H}$ \\
\hline 31. 1.2008 & $\begin{array}{l}\text { US-2008023888- } \\
\quad \text { A1 }\end{array}$ & $\begin{array}{l}\text { Method and apparatus for } \\
\text { production of meltblown } \\
\text { nanofibers }\end{array}$ & $\begin{array}{l}\text { J. Brang, } \\
\text { A. Wilkie, } \\
\text { J. Haggard }\end{array}$ & $\begin{array}{l}\text { A MB spinneret die having spin holes formed by grooves in plate(s) surface(s) of plate(s) where } \\
\text { polymer exits at the plate(s) edge(s). The grooves are } 0.127 \mathrm{~mm} \text { in wide and } 0.102 \mathrm{~mm} \text { deep or } \\
\text { smaller. The spin hole L/D ratios are } 20 / 1 \text { or greater, preferably as high as } 200 / 1 \text { or even } 1000 / 1 \text {. } \\
\text { Spin holes are arranged in linear arrays with a density of } 99 \text { or even } 199 \text { holes per inch. [37] }\end{array}$ & I \\
\hline 9. 3.2017 & $\begin{array}{l}\text { US-2017067184- } \\
\quad \text { A1 }\end{array}$ & $\begin{array}{l}\text { Melt blowing die, apparatus } \\
\text { and method }\end{array}$ & M. A. Allen & $\begin{array}{l}\text { A melt blowing die includes a stack of plates including corresponding melt blowing die tip, die } \\
\text { body and air functionalities. The stack may include at least 20-60 plates per centimeter of length } \\
\text { and } 1-20 \text { rows of orifices. [38] }\end{array}$ & $\mathrm{J}$ \\
\hline 16. 11.2017 & $\begin{array}{l}\text { JP-2017203233- } \\
\text { A }\end{array}$ & Melt-blowing die & $\begin{array}{l}\text { H. Adachi, } \\
\text { Y. Miura }\end{array}$ & $\begin{array}{c}\text { MB die is special by two air channels: a primary air flow passage which is provided such that the } \\
\text { resin flow passage is interposed therein, and which blows primary air downward against the } \\
\text { molten resin discharged through the resin flow passage; and a secondary air flow passage which is } \\
\text { provided such that the primary air flow passage is interposed therein, and which blows secondary } \\
\text { air from the outside of the primary air. [39] }\end{array}$ & K \\
\hline
\end{tabular}


TABLE 2a. Effect of meltblown process variables on fiber diameter (adapted from [1] and upgraded).

\begin{tabular}{|c|c|c|c|c|c|c|c|c|c|c|c|c|c|}
\hline \multirow[b]{2}{*}{$\begin{array}{l}\text { Principle } \\
\text { Investigator }\end{array}$} & \multirow[b]{2}{*}{ Researchers } & Dependent & \multicolumn{11}{|c|}{ Independent Variables } \\
\hline & & $\begin{array}{l}\text { Mean Fiber } \\
\text { Diameter }\end{array}$ & $\begin{array}{c}\text { Polymer } \\
\text { Throughput }\end{array}$ & $\begin{array}{l}\text { Polymer } \\
\text { Temp. }\end{array}$ & MFI & $\begin{array}{l}\text { Air } \\
\text { Flow } \\
\text { Rate }\end{array}$ & $\begin{array}{c}\text { Air } \\
\text { Velocity }\end{array}$ & $\begin{array}{c}\text { Air } \\
\text { Pressure }\end{array}$ & $\begin{array}{c}\text { Air } \\
\text { Temp. }\end{array}$ & $\begin{array}{l}\text { Die } \\
\text { Temp. }\end{array}$ & DCD & $\begin{array}{l}\text { Average } \\
\text { fiber } \\
\text { diameter } \\
{[\mu \mathrm{m}]}\end{array}$ & Others \\
\hline \multirow{6}{*}{ Chen } & Chen \& Huang (2003) [40] & $\downarrow$ & $\downarrow$ & $\uparrow$ & - & - & $\uparrow$ & - & $\uparrow$ & - & - & - & $\begin{array}{c}\downarrow \text { angle between the slot and } \\
\text { the spinneret axis } \\
\downarrow \text { die head width } \\
\uparrow \text { slot width }\end{array}$ \\
\hline & Chen \& Huang (2004) [41] & $\downarrow$ & - & - & - & - & $\uparrow$ & - & - & - & - & - & - \\
\hline & $\begin{array}{l}\text { Chen, Wang, \& Huang (2004) } \\
\text { [42] }\end{array}$ & $\downarrow$ & - & - & - & - & - & - & - & - & - & - & $\begin{array}{c}\downarrow \text { angle between the slot and } \\
\text { the spinneret axis } \\
\downarrow \text { die head width } \\
\uparrow \text { slot width }\end{array}$ \\
\hline & Chen, Li, \& Huang (2005) [43] & $\downarrow$ & $\downarrow$ & - & - & - & $\uparrow$ & - & - & - & $\uparrow$ & $4.24-8.58$ & - \\
\hline & $\begin{array}{l}\text { Chen, Wang, \& Huang (2005a) } \\
\text { [44] }\end{array}$ & $\downarrow$ & $\downarrow$ & $\uparrow$ & $\uparrow$ & - & $\uparrow$ & - & $\mathrm{n} / \mathrm{a}^{*}$ & - & - & $8.24-20.08$ & - \\
\hline & Wu, Huang \& Chen (2014) [45] & $\downarrow$ & $\downarrow$ & - & - & - & $\uparrow$ & - & - & - & - & $0.17-0.90$ & - \\
\hline \multirow{8}{*}{ 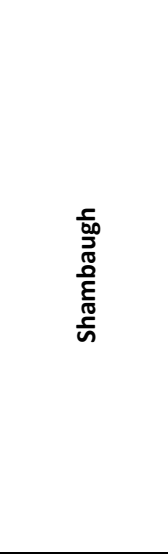 } & $\begin{array}{l}\text { Kayser \& Shambaugh (1990) } \\
\text { [46] }\end{array}$ & $\uparrow$ & $\uparrow$ & - & - & - & - & - & - & - & - & $\begin{array}{c}14.45^{+}- \\
50.41^{+}\end{array}$ & $\begin{array}{c}\text { Capillary diameter }\left(\mathrm{d}_{1}\right) \uparrow \\
\text { Air to polymer mass flow ratio } \downarrow \\
\text { Air to polymer mass flux ratio } \downarrow\end{array}$ \\
\hline & $\begin{array}{l}\text { Uyttendaele \& Shambaugh } \\
\text { (1990) [47] }\end{array}$ & $\downarrow$ & - & - & - & - & - & - & - & - & $\uparrow$ & - & 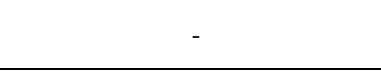 \\
\hline & Rao \& Shambaugh (1993) [19] & $\downarrow$ & $\downarrow$ & $\uparrow$ & - & - & $\uparrow$ & - & $\uparrow$ & - & - & - & - \\
\hline & $\begin{array}{l}\text { Tyagi \& Shambaugh (1995) } \\
\text { [48] }\end{array}$ & $\uparrow$ & $\uparrow$ & $\downarrow$ & - & $\downarrow$ & - & - & $\downarrow$ & - & - & $\begin{array}{c}38.40- \\
76.80\end{array}$ & $\begin{array}{c}\text { Fiber diameter decreases if } \\
\text { oscillating air is used instead of } \\
\text { continuous air }\end{array}$ \\
\hline & $\begin{array}{l}\text { Marla \& Shambaugh (2003) } \\
\text { [49] }\end{array}$ & $\downarrow$ & - & - & - & - & $\uparrow$ & - & - & - & - & - & - \\
\hline & $\begin{array}{l}\text { Marla \& Shambaugh (2004) } \\
\text { [50] }\end{array}$ & $\downarrow$ & $\downarrow$ & $\uparrow$ & - & - & - & - & $\uparrow$ & - & - & $\begin{array}{l}30.00- \\
126.00\end{array}$ & - \\
\hline & Moore et al. (2004) [51] & $\uparrow$ & $\uparrow$ & - & - & $\downarrow$ & - & - & - & - & - & $3.50-13.90$ & - \\
\hline & $\begin{array}{l}\text { Shambaugh, Papavassiliou \& } \\
\text { Shambaugh (2011) [52] }\end{array}$ & $\downarrow$ & - & - & - & $\downarrow$ & - & - & - & - & - & - & - \\
\hline \multirow{5}{*}{ 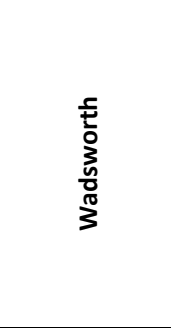 } & $\begin{array}{l}\text { Jones \& Wadsworth (1986) } \\
\text { [53] }\end{array}$ & $\uparrow$ & & & & & & & & & $\downarrow$ & - & - \\
\hline & Choi et al. (1988) [54] & $\downarrow$ & - & - & - & - & - & $\uparrow$ & - & $\uparrow$ & - & $4.01^{+}-7.75^{+}$ & - \\
\hline & Lee \& Wadsworth (1990) [55] & $\downarrow$ & - & - & - & $\uparrow$ & - & - & $\uparrow$ & $\uparrow$ & $\begin{array}{l}\mathrm{n} / \mathrm{a} \text { after } \\
30 \mathrm{~cm}^{*}\end{array}$ & $4.50-19.10$ & - \\
\hline & Milligan et al. (1992) [56] & $\downarrow$ & $\downarrow$ & $\uparrow$ & - & - & $\uparrow$ & - & - & - & - & $2.83-10.89$ & $\begin{array}{l}\text { Fiber diameter decreases if } \\
\text { additional crossflow air is used }\end{array}$ \\
\hline & Sun et al. (1996) [57] & $\downarrow$ & $\downarrow$ & $\uparrow$ & - & - & - & $\uparrow$ & $\uparrow$ & - & - & $\begin{array}{l}1.24^{+}- \\
17.52^{+}\end{array}$ & - \\
\hline
\end{tabular}

Note. The ${ }^{*}$ indicates a disagreement among researchers; ${ }^{+}$digitized data from figures provided in given reference. 
TABLE 2b. Effect of meltblown process variables on fiber diameter (adapted from [1] and upgraded).

\begin{tabular}{|c|c|c|c|c|c|c|c|c|c|c|c|c|c|}
\hline \multirow[b]{2}{*}{$\begin{array}{l}\text { Principle } \\
\text { Investigator }\end{array}$} & \multirow[b]{2}{*}{ Researchers } & Dependent & \multicolumn{11}{|c|}{ Independent Variables } \\
\hline & & $\begin{array}{l}\text { Mean Fiber } \\
\text { Diameter }\end{array}$ & $\begin{array}{l}\text { Polymer } \\
\text { Throughput }\end{array}$ & $\begin{array}{l}\text { Polymer } \\
\text { Temp. }\end{array}$ & MFI & $\begin{array}{l}\text { Air Flow } \\
\text { Rate }\end{array}$ & $\begin{array}{c}\text { Air } \\
\text { Velocity }\end{array}$ & $\begin{array}{c}\text { Air } \\
\text { Pressure }\end{array}$ & $\begin{array}{l}\text { Air } \\
\text { Temp. }\end{array}$ & $\begin{array}{l}\text { Die } \\
\text { Temp. }\end{array}$ & DCD & $\begin{array}{l}\text { Average } \\
\text { fiber } \\
\text { diameter } \\
{[\mu \mathrm{m}]}\end{array}$ & Others \\
\hline & Wente et al. (1954) [58] & $\uparrow$ & $\uparrow$ & - & - & - & - & $\downarrow$ & $\downarrow$ & $\downarrow$ & - & $0.30-2.00$ & - \\
\hline & Malkan (1990) [59] & 个 & 个 & - & - & - & - & - & - & - & - & $2.80-6.70$ & - \\
\hline & Haynes (1991) [60] & $\downarrow$ & $\downarrow$ & - & - & - & $\uparrow$ & - & $\uparrow$ & $\uparrow$ & - & $3.61-33.88$ & DCD is insignificant \\
\hline & $\begin{array}{l}\text { Straeffer \& Goswami (1992) } \\
\text { [61] }\end{array}$ & $\uparrow$ & $\uparrow$ & - & $\mathrm{n} / \mathrm{a}^{*}$ & - & $\downarrow$ & - & - & - & - & - & 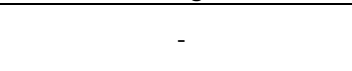 \\
\hline & Khan (1993) [62] & $\downarrow$ & $\downarrow$ & - & - & $\uparrow$ & - & - & - & - & - & $1.72-3.34$ & DCD is insignificant \\
\hline & Zhang et al. (2002) [63] & $\downarrow$ & $\downarrow$ & $\uparrow$ & - & $\uparrow$ & - & - & $\uparrow$ & - & - & $1.71-4.76$ & - \\
\hline & Bresee \& Qureshi (2006) [64] & $\downarrow$ & $\downarrow$ & - & - & $\uparrow$ & - & - & - & $\uparrow$ & $\uparrow$ & $6.79^{+}-25.93^{+}$ & Collector speed n/a \\
\hline & Ellison et al. (2007) [18] & $\begin{array}{l}\downarrow \\
\downarrow\end{array}$ & 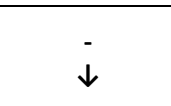 & - & - & $\begin{array}{l}\uparrow \\
-\end{array}$ & - & - & - & $\begin{array}{l}- \\
-\end{array}$ & - & $0.30-1.61$ & $\begin{array}{c}\text { 个 Air to polymer mass flux } \\
\text { ratio } \\
-\end{array}$ \\
\hline & Duran \& Perincek (2010) [65] & $\downarrow$ & $\downarrow$ & - & - & - & - & $\uparrow$ & - & - & $\mathrm{n} / \mathrm{a}^{*}$ & $4.47-7.70$ & - \\
\hline & Tan et al. (2010) [23] & $\uparrow$ & - & - & - & - & - & - & - & - & - & $0.62-7.55$ & $\begin{array}{c}\uparrow \text { Melt viscosity or } \\
\downarrow \text { Elasticity }\end{array}$ \\
\hline & Jarecki et al. (2011) [26] & $\downarrow$ & - & - & - & - & - & - & $\uparrow$ & - & - & - & - \\
\hline & Zeng et al. (2011) [66] & $\downarrow$ & - & - & - & - & $\uparrow$ & - & - & - & - & - & - \\
\hline & Duran et al. (2013) [67] & $\downarrow$ & - & - & - & - & - & $\uparrow$ & - & - & - & $5.00-7.50$ & $\begin{array}{l}\uparrow \text { Collector speed or } \\
\downarrow \text { Collector vacuum }\end{array}$ \\
\hline & Han et al. (2013) [68] & $\downarrow$ & - & - & - & $\uparrow$ & - & $\uparrow$ & - & - & - & $1.04-0.60$ & - \\
\hline & Hassan et al. (2013) [69] & $\downarrow$ & $\downarrow$ & - & - & - & - & - & - & - & - & $0.30-1.50$ & - \\
\hline & Wang \& Wang (2013) [70] & $\downarrow$ & - & - & - & - & $\uparrow$ & - & - & - & - & - & - \\
\hline & Nayak et al. (2015) [71] & $\downarrow$ & - & - & $\uparrow$ & - & - & - & - & - & $\uparrow$ & $0.59-1.20$ & - \\
\hline & Zhao (2015) [72] & $\downarrow$ & - & - & - & - & $\uparrow$ & - & $\uparrow$ & - & - & - & - \\
\hline & Guo et al. (2016) [73] & $\begin{array}{c}\downarrow \\
\mathrm{n} / \mathrm{a}^{*}\end{array}$ & $\begin{array}{l}\downarrow \\
-\end{array}$ & - & - & - & - & $\begin{array}{l}- \\
-\end{array}$ & $\begin{array}{l}\uparrow \\
-\end{array}$ & - & $\begin{array}{l} \\
\uparrow\end{array}$ & $3.00-10.50$ & $\begin{array}{l}- \\
-\end{array}$ \\
\hline & Renukarn et al. (2016) [74] & $\downarrow$ & $\downarrow$ & - & - & - & - & - & - & - & - & $0.59-3.99$ & $\downarrow$ Spinneret diameter \\
\hline & Ruamsuk et al. (2016) [75] & $\downarrow$ & $\downarrow$ & - & - & $\uparrow$ & - & - & - & - & - & $2.20-9.50$ & - \\
\hline & Yesil \& Bhat (2016) [76] & $\downarrow$ & - & - & - & - & - & $\uparrow$ & - & - & $\uparrow$ & $11.50-24.70$ & - \\
\hline & Feng (2017) [77] & $\downarrow$ & - & - & - & - & - & - & - & - & $\uparrow$ & $2.41^{+}-6.87^{+}$ & - \\
\hline & Sun et al. (2018) [78] & $\downarrow$ & - & - & - & - & - & - & - & - & $\uparrow$ & - & - \\
\hline & Hao et al. (2018) [79] & $\downarrow$ & $\downarrow$ & - & - & $\uparrow$ & - & - & - & - & - & $\begin{array}{c}14.63^{+}- \\
18.27^{+}\end{array}$ & Polymer with smaller viscosity \\
\hline
\end{tabular}

Note. The * indicates a disagreement among researchers; ${ }^{+}$digitized data from figures provided in given reference. 
TABLE 3a. Effect of meltblown process variables on basic nonwoven characteristics (adapted from [1] and upgraded based on the recent open literature)

\begin{tabular}{|c|c|c|c|c|c|c|c|c|c|}
\hline \multirow[b]{2}{*}{ Researchers } & \multirow[b]{2}{*}{ Independent Variables } & \multicolumn{8}{|c|}{ Dependent Variables } \\
\hline & & $\begin{array}{c}\text { Fiber } \\
\text { Entanglement }\end{array}$ & $\begin{array}{c}\text { Pore } \\
\text { Structure } \\
\text { (cover) }\end{array}$ & $\begin{array}{c}\text { Mean } \\
\text { Pore } \\
\text { Size }\end{array}$ & $\begin{array}{c}\text { Air } \\
\text { Permeability }\end{array}$ & Tenacity & $\begin{array}{l}\text { Elongation } \\
\text { at Break }\end{array}$ & Otr & \\
\hline \multirow{3}{*}{ Choi et al. (1988) [54] } & $\uparrow$ Die temperature & - & - & - & - & $\downarrow$ & $\downarrow$ & $\downarrow$ Young's modulus & $\downarrow$ Bending rigidity \\
\hline & 个 Air pressure & - & - & - & - & $\downarrow$ & $\downarrow$ & $\downarrow$ Young's modulus & $\downarrow$ Bending rigidity \\
\hline & $\uparrow D C D$ & - & - & - & - & $\downarrow$ & $\uparrow$ & $\downarrow$ Young's modulus & $\downarrow$ Bending rigidity \\
\hline \multirow{3}{*}{ Lee \& Wadsworth (1990) [55] } & $\begin{array}{l}\text { 个 Processing temp. (die } \\
\text { temp. \& air temp.) }\end{array}$ & $\uparrow$ & - & $\downarrow$ & $\downarrow$ & - & - & \multicolumn{2}{|l|}{ 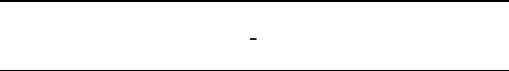 } \\
\hline & $\uparrow$ Air flow rate & 个* & - & $\downarrow$ & $\downarrow$ & - & - & \multicolumn{2}{|c|}{-} \\
\hline & $\downarrow D C D$ & 个* & - & $\downarrow$ & $\downarrow$ & - & - & \multicolumn{2}{|c|}{ - } \\
\hline $\begin{array}{l}\text { Uyttendaele \& Shambaugh } \\
\text { (1990) [47] }\end{array}$ & $\uparrow D C D$ & - & - & - & - & - & - & $\uparrow$ Fiber velocity & $\downarrow$ Gas velocity \\
\hline Malkan (1990) [59] & $\uparrow$ Polymer flow rate & - & - & - & $\uparrow$ & - & - & \multicolumn{2}{|c|}{-} \\
\hline \multirow{2}{*}{ Straeffer \& Goswami (1992) [61] } & 个 Air flow rate & - & - & - & - & $\uparrow$ & $\downarrow$ & $\uparrow$ Yield stress & 个 Initial modulus \\
\hline & $\downarrow$ Polymer flow rate & - & - & - & - & $\uparrow$ & $\downarrow$ & $\uparrow$ Yield stress & 个 Initial modulus \\
\hline Wu \& Shambaugh (1992) [80] & 个DCD & - & - & - & - & - & - & \multicolumn{2}{|c|}{$\downarrow$ Fiber velocity (revised from [47]) } \\
\hline Milligan et al. (1992) [56] & Use of crossflow air & $\uparrow$ & - & - & $\uparrow$ & $\uparrow$ & $\uparrow$ & \multicolumn{2}{|c|}{ 个 Bursting strength } \\
\hline \multirow{2}{*}{ Khan (1993) [62] } & 个 Air flow rate & - & - & - & $\uparrow$ & - & - & \multicolumn{2}{|c|}{-} \\
\hline & 个 Polymer flow rate & - & - & - & - & $\uparrow$ & $\downarrow$ & \multicolumn{2}{|c|}{-} \\
\hline \multirow{2}{*}{ Qureshi (2001) [81] } & 个DCD & $\uparrow$ & - & - & - & - & - & \multicolumn{2}{|c|}{$\downarrow$ Fiber flow divergence } \\
\hline & $\downarrow D C D$ & - & - & - & - & - & - & \multicolumn{2}{|c|}{$\uparrow$ Orientation in webs } \\
\hline \multirow{4}{*}{ Zhang et al. (2002) [63] } & $\uparrow$ Melt temperature & - & - & - & $\downarrow$ & $\uparrow$ & $\downarrow$ & \multicolumn{2}{|c|}{$\downarrow$ Hydrostatic head } \\
\hline & $\uparrow$ Polymer flow rate & - & - & - & - & - & - & $\downarrow$ Hydrostatic head & $\downarrow$ Bulk density \\
\hline & 个 Air temperature & - & - & - & - & $\uparrow$ & - & \multicolumn{2}{|l|}{-} \\
\hline & $\uparrow$ Air flow rate & - & - & - & - & $\uparrow$ & - & \multicolumn{2}{|c|}{-} \\
\hline
\end{tabular}

Note. The * indicates a disagreement with Qureshi (2001) [81], Bresee \& Qureshi (2004) [82] and Bresee et al. (2005) [83]. 
TABLE 3b. Effect of meltblown process variables on basic nonwoven characteristics (adapted from [1] and upgraded based on the recent open literature)

\begin{tabular}{|c|c|c|c|c|c|c|c|c|}
\hline \multirow[b]{2}{*}{ Researchers } & \multirow[b]{2}{*}{ Independent Variables } & \multicolumn{7}{|c|}{ Dependent Variables } \\
\hline & & $\begin{array}{c}\text { Fiber } \\
\text { Entanglement }\end{array}$ & $\begin{array}{l}\text { Pore } \\
\text { Structure } \\
\text { (cover) }\end{array}$ & $\begin{array}{l}\text { Mean } \\
\text { Pore } \\
\text { Size }\end{array}$ & $\begin{array}{c}\text { Air } \\
\text { Permeability }\end{array}$ & Tenacity & $\begin{array}{l}\text { Elongation } \\
\text { at Break }\end{array}$ & Other \\
\hline Bresee and Ko (2003) [14] & $\uparrow D C D$ & 个* & - & - & - & - & - & - \\
\hline Bresee \& Qureshi (2004) [82] & $\uparrow D C D$ & 个* & $\uparrow$ & - & - & - & - & $\downarrow$ Fiber orientation \\
\hline Bresee et al. (2005) [83] & $\uparrow$ Air flow rate & $\downarrow^{*}$ & $\downarrow$ & - & - & - & - & $\uparrow$ Fiber orientation \\
\hline Zapletalova et al. (2006) [84] & $\uparrow D C D$ & - & - & - & - & $\downarrow$ & $\downarrow$ & - \\
\hline Duran \& Perincek (2010) [65] & $\begin{array}{l}\uparrow D C D \\
\uparrow \text { Air pressure }\end{array}$ & - & - & - & $\begin{array}{l}\uparrow \\
-\end{array}$ & - & $\begin{array}{l}\uparrow \\
-\end{array}$ & $\begin{array}{c}\text { 个 Thickness } \uparrow \text { Friction and surface is smoother } \\
\uparrow \text { Thickness }\end{array}$ \\
\hline \multirow{2}{*}{$\begin{array}{l}\text { Uppal, Bhat, Eash \& Akato (2012) } \\
\text { [85] }\end{array}$} & $\uparrow$ Air pressure & - & - & $\downarrow$ & - & - & - & $\begin{array}{c}\downarrow \text { Number average fiber diameter } \\
\uparrow \text { Filtration efficiency }\end{array}$ \\
\hline & $\uparrow D C D$ & - & - & $\downarrow$ & - & - & - & $\begin{array}{c}\downarrow \text { Number average fiber diameter } \\
\uparrow \text { Filtration efficiency }\end{array}$ \\
\hline Duran et al. (2013) [67] & $\begin{array}{l}\downarrow \text { Collector speed } \\
\downarrow \text { Collector vacuum } \\
\downarrow \text { Collector speed } \\
\uparrow \text { Air pressure } \\
\end{array}$ & - & - & - & $\begin{array}{l}- \\
\uparrow \\
\downarrow \\
\downarrow\end{array}$ & - & $\begin{array}{l}\uparrow \\
\downarrow \\
- \\
\downarrow\end{array}$ & $\begin{array}{c}\uparrow \text { Thickness } \\
\uparrow \text { Thickness } \\
- \\
-\end{array}$ \\
\hline Han et al. (2013) [68] & $\uparrow$ Hole density & $\uparrow$ & - & - & - & - & - & - \\
\hline Ghosal et al. (2016) [86] & $\begin{array}{l}\text { T Velocity of collector } \\
\text { screen }\end{array}$ & - & $\uparrow$ & - & $\uparrow$ & - & - & - \\
\hline Guo et al. (2016) [73] & $\begin{array}{l}\uparrow \text { Air temperature } \\
\uparrow \text { Polymer throughput } \\
\uparrow D C D\end{array}$ & $\begin{array}{l}- \\
- \\
-\end{array}$ & $\begin{array}{c}\mathrm{n} / \mathrm{a} \\
\downarrow \\
\uparrow\end{array}$ & $\begin{array}{l}- \\
- \\
-\end{array}$ & $\begin{array}{l}- \\
- \\
-\end{array}$ & $\begin{array}{l}- \\
- \\
-\end{array}$ & $\begin{array}{l}- \\
- \\
-\end{array}$ & $\begin{array}{c}\uparrow \text { Surface area } \\
\downarrow \text { Surface area } \\
\text { No change surface area }\end{array}$ \\
\hline Yesil \& Bhat (2016) [76] & $\uparrow D C D$ & $\downarrow$ & - & - & - & - & - & \\
\hline Feng et al. (2017) [77] & $\uparrow D C D$ & - & $\downarrow$ & $\downarrow$ & - & - & - & $\begin{array}{c}\downarrow \text { Stress } \\
\downarrow \text { Strain along length direction } \\
\text { No change alignment degree } \\
\text { No change apparent contact angle }\end{array}$ \\
\hline Sun et al. (2017) [87] & $\begin{array}{l}\text { 个 Polymer throughput } \\
\downarrow \text { Collection belt speed } \\
\downarrow \text { Air suction speed } \\
\downarrow \text { Air jet velocity } \\
\end{array}$ & - & - & - & - & - & - & $\downarrow$ Uniformity of the web structure \\
\hline Sun et al. (2018) [88] & $\begin{array}{l}\text { 个 Air jet velocity } \\
\uparrow \text { Speed of collector } \\
\uparrow \text { Air suction speed } \\
\uparrow D C D\end{array}$ & - & - & - & - & - & - & Gradual improvement of basis weight uniformity \\
\hline
\end{tabular}

Note. The * indicates a disagreement with the Lee \& Wadsworth (1990) [55] and Yesil \& Bhat (2016) [76]. 
Table 4. Typical polymers utilized in the MB technology $[1,96]$

\begin{tabular}{|l|l|}
\hline \multicolumn{1}{|c|}{ Common } & \multicolumn{1}{c|}{ Others } \\
\hline Polypropylene (PP) & Ethylene vinyl acetate (EVA) \\
\hline Polystyrene (PS) & Ethylene methacrylate (EMA) \\
\hline Polyesters & Ethylene vinyl alcohol (EVOH) \\
\hline Polyurethane (PUR) & Fusibles of copolymers \\
\hline Polyamide (PA 6, 66, 11, 12) & Polybutylene terephthalate (PBT) \\
\hline Polyethylene (PE) & Polyphenylene sulfide (PPS) \\
\hline \multirow{2}{*}{ Low and high density polyethylene (LDPE, } & \multirow{2}{*}{ Polymethylpentene (PMP) } \\
\hline Linear low-density polyethylene (LLDPE) & Polyvinyl alcohol (PVA) \\
\hline \multirow{5}{*}{ Polycarbonate (PC) } & Polyethylene sulfide \\
\cline { 2 - 2 } & Fluoropolymers \\
\cline { 2 - 2 } & Polytrifluorochloroethene (PCTFE) \\
\cline { 2 - 2 } & Polyethylene terephthalate (PET) \\
\cline { 2 - 2 } & Poly (4-methylpent-1-ene) \\
\cline { 2 - 2 } & Polytetramethylene Terephthalate (PTMT) \\
\cline { 2 - 2 } & Sulfopolyester \\
\cline { 2 - 2 } & Polyvinylidene fluoride (PVDF) \\
\hline
\end{tabular}


Table 5. Summarization of products, which can be produced by the MB technology [1] (adapted from [123])

\begin{tabular}{|l|l|}
\hline Field of applications & \multicolumn{1}{|c|}{ Products } \\
\hline Filtration & $\begin{array}{l}\text { Heating, ventilation, and air conditioning (HVCA) filter, high- } \\
\text { efficiency particulate air (HEPA) filter, ultra low particulate air } \\
\text { (ULPA) filter, oil filter, respiratory filter, teabags, vacuum cleaner } \\
\text { filter bags, dry and liquid aerosol filter, odour control, activated carbon } \\
\text { filter, liquid filters. }\end{array}$ \\
\hline Medical & $\begin{array}{l}\text { Surgical gowns, face masks, drapes, caps, bandages, tapes, wound } \\
\text { dressings, pads, sponges, cover stocks, sterile packaging, heat pack. }\end{array}$ \\
\hline Sorbents \&Wipes & $\begin{array}{l}\text { Household wipes, industrial clean up wipes, oil clean up (oil booms), } \\
\text { food fat absorption }\end{array}$ \\
\hline Hygiene & $\begin{array}{l}\text { Baby diapers, feminine sanitary napkins, adult incontinence pads, } \\
\text { tampons, nasal trips. }\end{array}$ \\
\hline Industrial & $\begin{array}{l}\text { Absorbent, lubricating pads, papermaking felts, conveyor belts, } \\
\text { packaging, artificial leathers, battery separator, abrasives. }\end{array}$ \\
\hline Automobiles & $\begin{array}{l}\text { Side, front and back liner, floor mat, sheet cover, wheelhouse cover, oil } \\
\text { filter, engine air filter, sounds absorbing panel. }\end{array}$ \\
\hline Agriculture & $\begin{array}{l}\text { Root bags, weed control fabric, water retention fabric, crop cover or } \\
\text { seed protector, soil separation, capillary mat, containers. }\end{array}$ \\
\hline Geotextiles & $\begin{array}{l}\text { Pond and river liner for erosion control, soil stabilization, road bed, } \\
\text { drainage. }\end{array}$ \\
\hline $\begin{array}{l}\text { Construction and } \\
\text { civil engineering }\end{array}$ & $\begin{array}{l}\text { Insulation nonwoven, pipe wrap, insulation ceilings or false ceiling, } \\
\text { house wrap, shingle. }\end{array}$ \\
\hline Household & $\begin{array}{l}\text { Cushion covers, blankets, bed sheets, quilt back, pillow covers, } \\
\text { curtains, envelopes, aprons, dust cloth, compact disc (CD) case, wall } \\
\text { paper, carpet backings, bags. }\end{array}$ \\
\hline Clothing & $\begin{array}{l}\text { Interlinings, pads, disposable underwear, shoe, belt and bag } \\
\text { components, labels, handkerchiefs, towels, dust removal cloths. }\end{array}$ \\
\hline Protection & $\begin{array}{l}\text { Fire protection fabrics, gas and chemical protection fabrics, thermal } \\
\text { insulating gloves, lab coats, ballistics armour, bullet proof vest. }\end{array}$ \\
\hline Transportation & $\begin{array}{l}\text { Cable insulation, semiconductor polishing pad, insulating tape, battery } \\
\text { separators. }\end{array}$ \\
\hline Other & Hot-melt adhesives, apparel thermal insulator, acoustic insulation. \\
\hline
\end{tabular}


TABLE 6. Summarization of the polymeric nanofibers produced via meltblown technology

\begin{tabular}{|c|c|c|}
\hline $\begin{array}{c}\text { Mean Fiber } \\
\text { Diameter } \\
{[\mathrm{nm}]}\end{array}$ & Reference & Material* \\
\hline 300 & [18] & \multirow{23}{*}{ PP } \\
\hline 320 & [27] & \\
\hline $334^{+}$ & [69] & \\
\hline $390^{+}$ & [69] & \\
\hline $398^{+}$ & [69] & \\
\hline 438 & [135] & \\
\hline 450 & {$[18]$} & \\
\hline 470 & [27] & \\
\hline $523^{+}$ & [69] & \\
\hline $524^{+}$ & [69] & \\
\hline $527^{+}$ & [69] & \\
\hline $532^{+}$ & [69] & \\
\hline $598^{+}$ & [68] & \\
\hline $634^{+}$ & [69] & \\
\hline $635^{+}$ & [68] & \\
\hline $694^{+}$ & [68] & \\
\hline $725^{+}$ & [68] & \\
\hline 755 & [135] & \\
\hline $765^{+}$ & {$[68]$} & \\
\hline 774 & [135] & \\
\hline $804^{+}$ & {$[68]$} & \\
\hline $869^{+}$ & [69] & \\
\hline 960 & {$[10]$} & \\
\hline 66 & [137] & \multirow{15}{*}{ PBT } \\
\hline 71 & [137] & \\
\hline 82 & [137] & \\
\hline 86 & {$[96]^{* *}$} & \\
\hline 99 & {$[96]^{* *}$} & \\
\hline 137 & {$[96]^{* *}$} & \\
\hline 152 & {$[96]^{* *}$} & \\
\hline 165 & {$[96]^{* *}$} & \\
\hline 171 & {$[96]^{* *}$} & \\
\hline 250 & {$[136]$} & \\
\hline 289 & {$[96]^{* *}$} & \\
\hline 311 & {$[96]^{* *}$} & \\
\hline 341 & {$[96]^{* *}$} & \\
\hline 350 & {$[96]^{* *}$} & \\
\hline 440 & {$[18]$} & \\
\hline 380 & [18] & \multirow{2}{*}{ PS } \\
\hline 620 & [18] & \\
\hline 70 & $\begin{array}{l}{[136]} \\
\end{array}$ & PECTFE \\
\hline$\frac{200}{36}$ & \multirow{7}{*}[96]{$^{* * *}$} & \multirow{7}{*}{ PVDF } \\
\hline 37 & & \\
\hline 72 & & \\
\hline 116 & & \\
\hline 131 & & \\
\hline 175 & & \\
\hline 184 & & \\
\hline
\end{tabular}

+ Digitized data from figures provided in given references.

*PP - polypropylene, PBT - polybutytelenterephthalate, PS - polystyrene, PECTFE - polyethylene-cochlorotrifluoroethylene, PVDF - polyvinylidene fluoride, SP - sulfonated polyethylene terephthalate. **PBT nanofibers extracted from PBT/PS meltblown microfibers

***PVDF nanofibers extracted from PVDF/SP meltblown microfibers 
TABLE 7. Effect of processing variables on flow instabilities/defects

\begin{tabular}{|c|c|c|c|c|c|}
\hline \multirow{2}{*}{$\begin{array}{c}\text { Flow } \\
\text { instability }\end{array}$} & \multicolumn{5}{|c|}{ Dependent Variables } \\
\hline & Air speed & $\begin{array}{c}\text { Polymer flow } \\
\text { rate }\end{array}$ & Temperature & DCD & $\begin{array}{c}\text { Collector } \\
\text { speed }\end{array}$ \\
\hline Whipping $\uparrow$ & $\uparrow$ & $\downarrow$ & $\downarrow$ & $\downarrow$ & - \\
\hline Die drool $\uparrow$ & $\uparrow$ & $\uparrow$ & $\uparrow$ & - & - \\
\hline Fiber breakup $\uparrow$ & $\uparrow$ & $\downarrow$ & $\uparrow$ & $\downarrow$ & - \\
\hline Melt spraying $\uparrow$ & $\uparrow$ & $\downarrow$ & $\uparrow$ & $\downarrow$ & - \\
\hline Flies $\uparrow$ & $\uparrow$ & $\downarrow$ & - & $\uparrow$ & $\uparrow$ \\
\hline $\begin{array}{l}\text { Generation of } \\
\text { small isolated } \\
\text { spherical } \\
\text { particles } \uparrow\end{array}$ & $\uparrow$ & $\downarrow$ & $\uparrow$ & $\downarrow$ & - \\
\hline Shots $\uparrow$ & $\downarrow$ & $\uparrow$ & $\uparrow$ & $\downarrow$ & $\uparrow$ \\
\hline Jam $\uparrow$ & $\downarrow^{*}$ & - & - & $\uparrow *$ & - \\
\hline
\end{tabular}

Note. The * indicates a disagreement with the Lee \& Wadsworth (1990) [55] and Yesil \& Bhat (2016) [76]. 


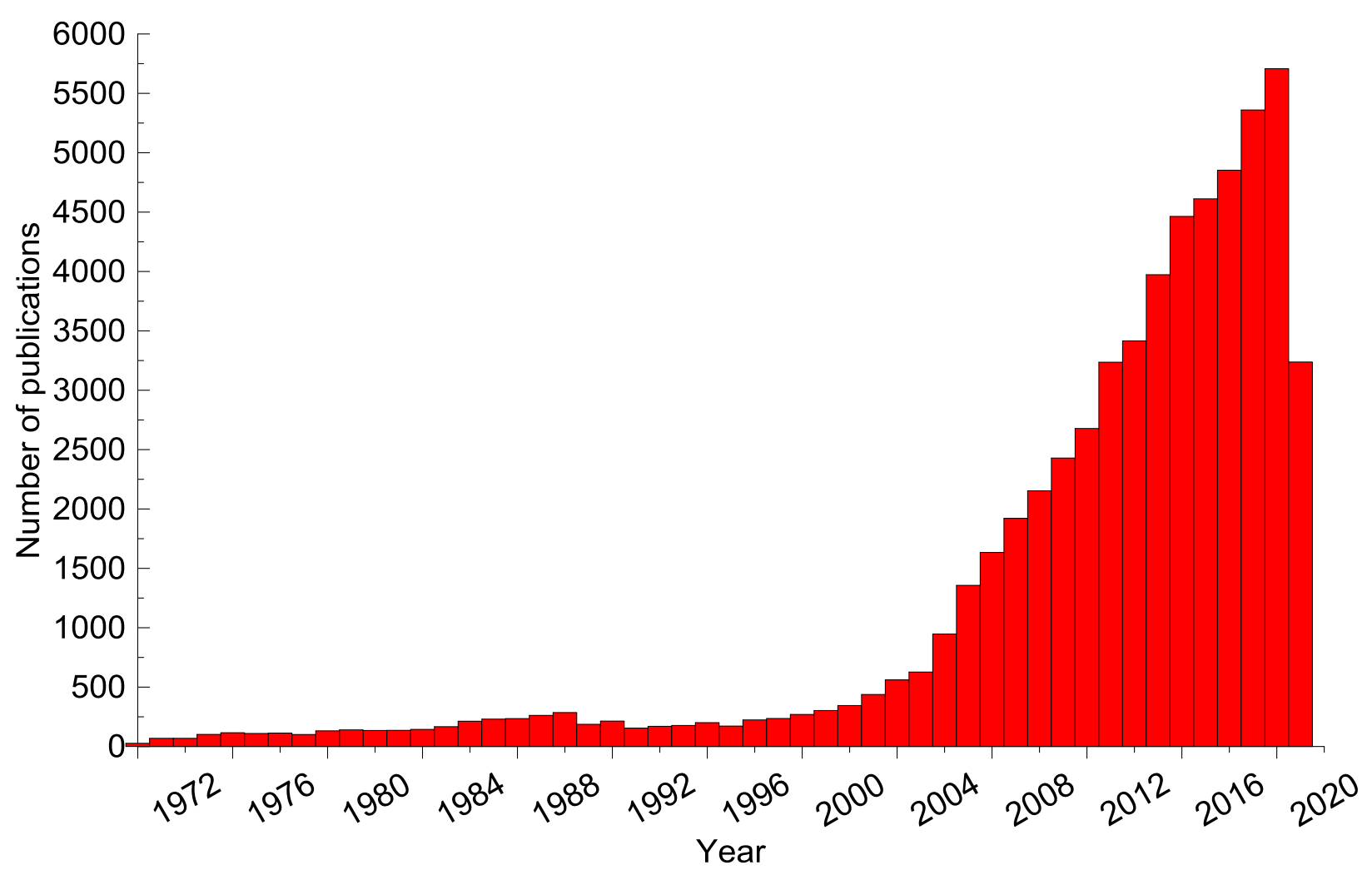

FIGURE 1: Development of publication activity about nanofibers, nonwovens and meltblown (data taken in June 2019 from [6]). 


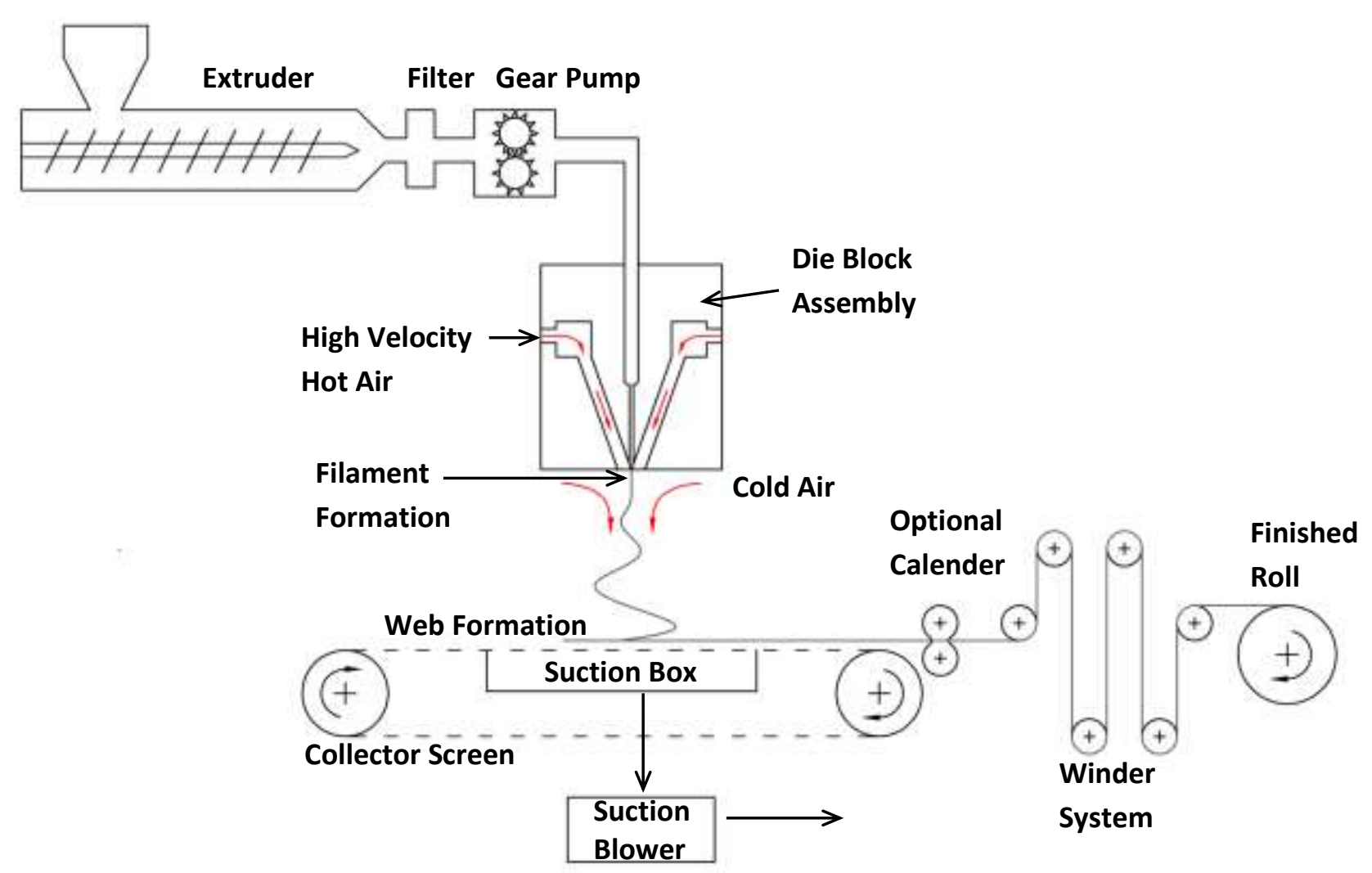

FIGURE 2: Sketch of meltblown line $[1,7,16]$. Reprinted with permission from [16]. Copyright 2019, The Society of Rheology. 


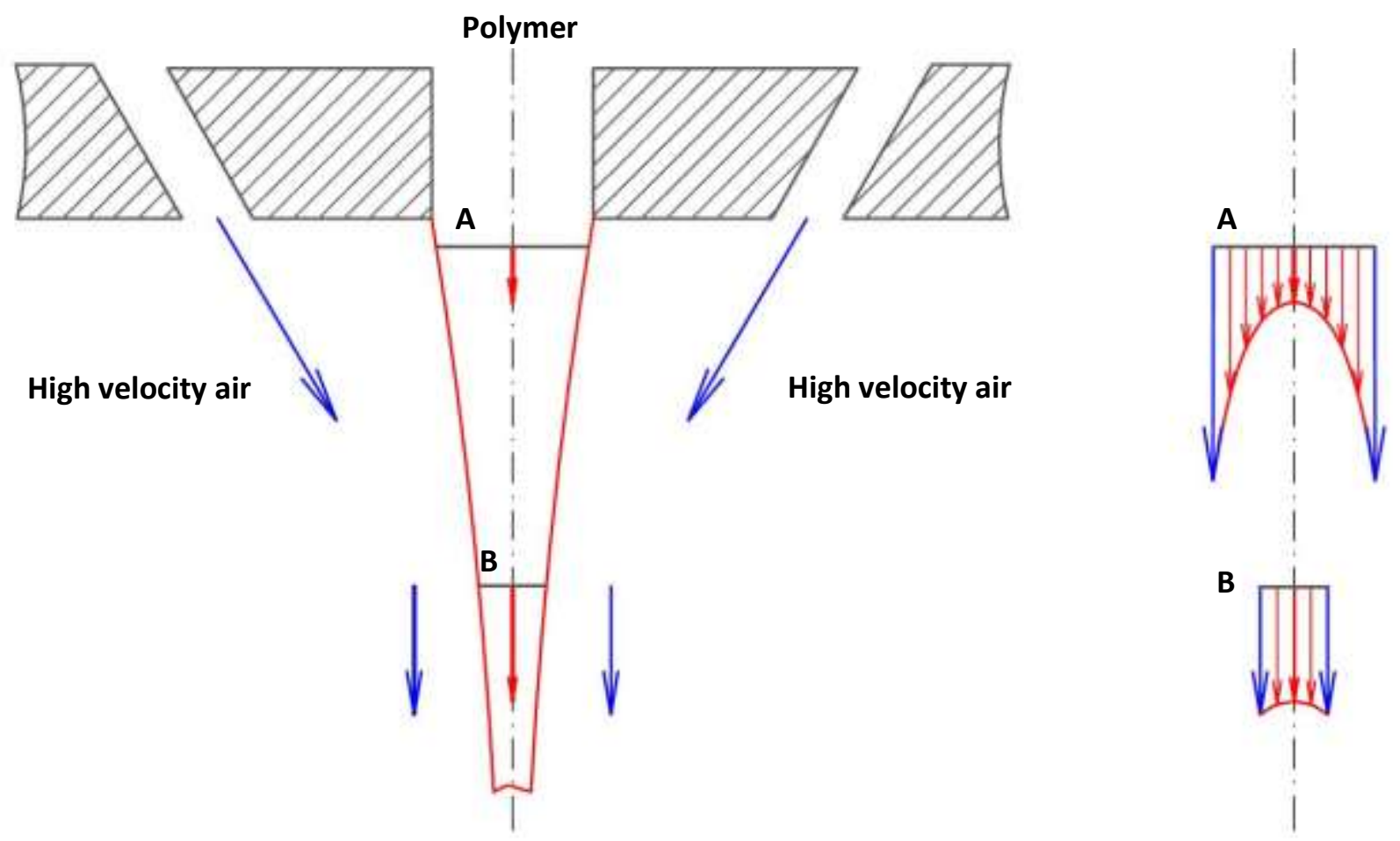

FIGURE 3: Visualization of fiber attenuation in post die area during MB process (left) together with particular velocity profiles in cross sections A and B (right) [1617]. 

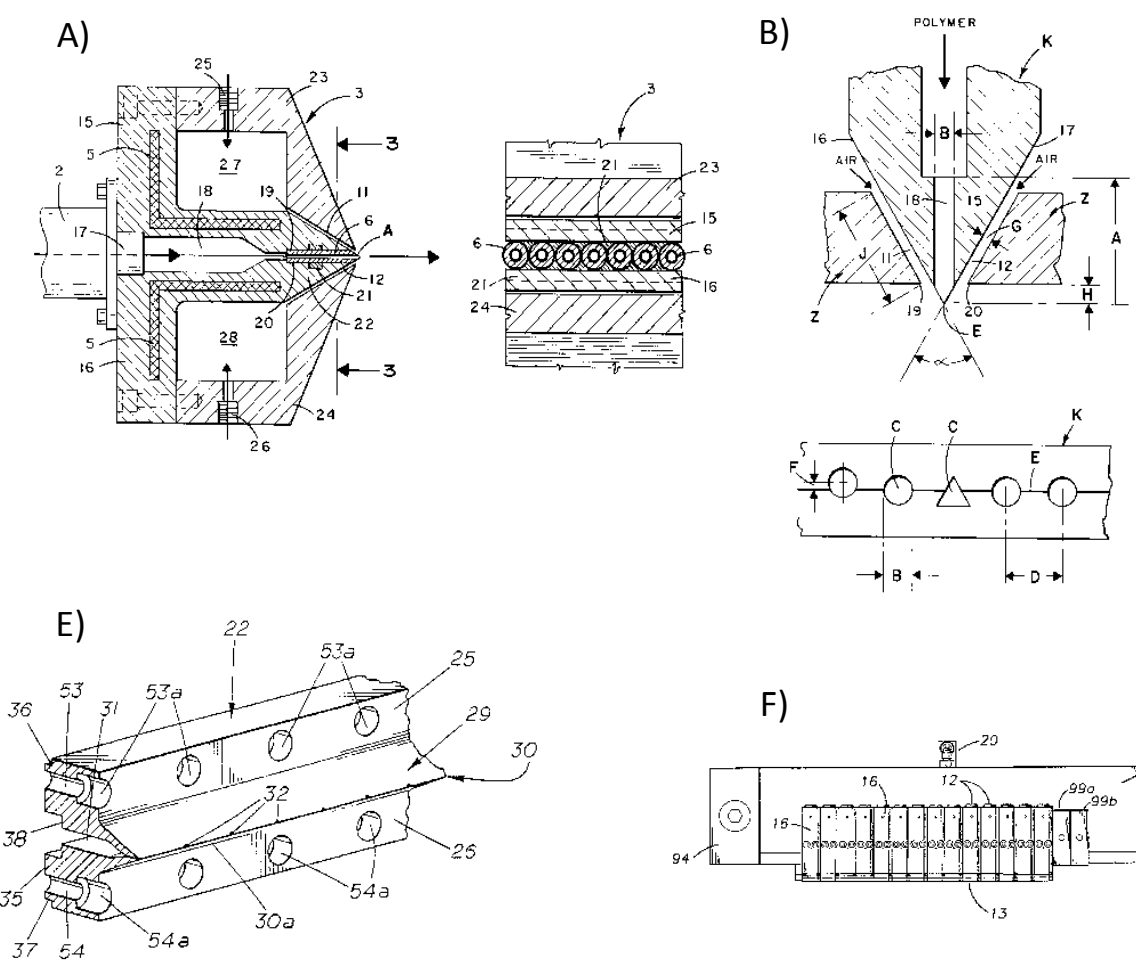

I)

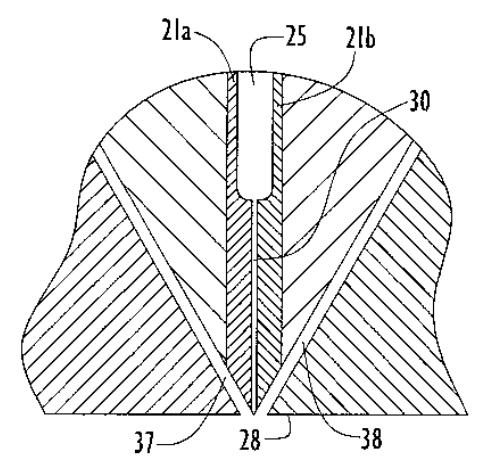

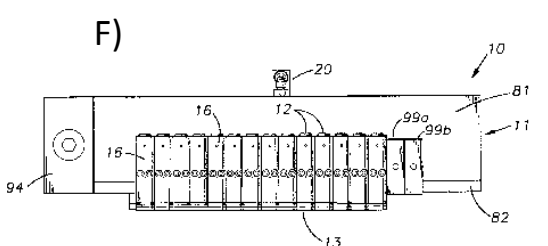

J)
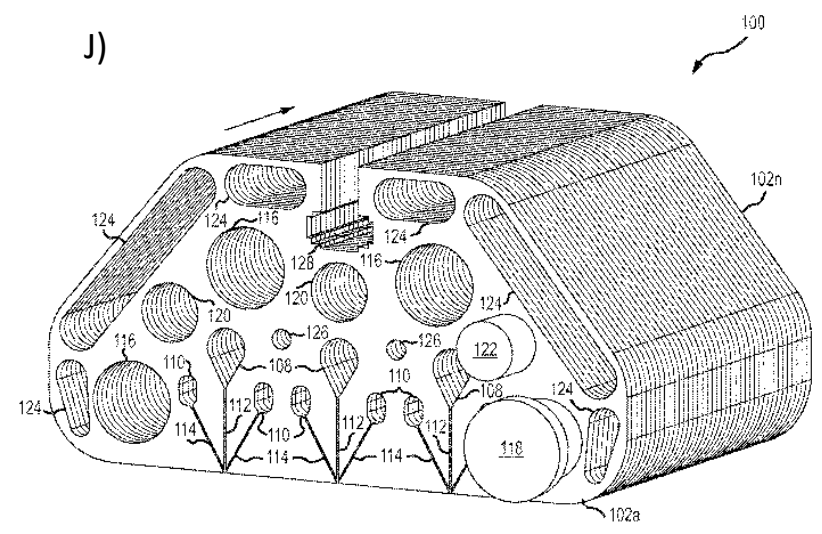

C)

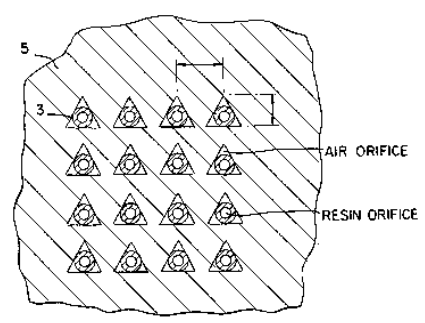

G)

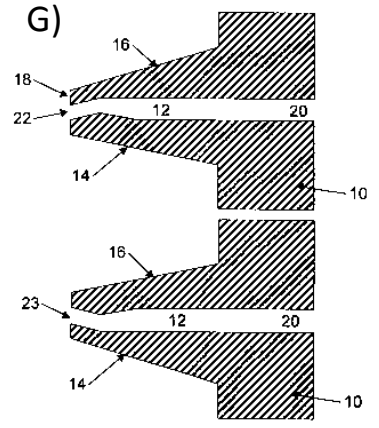

K)
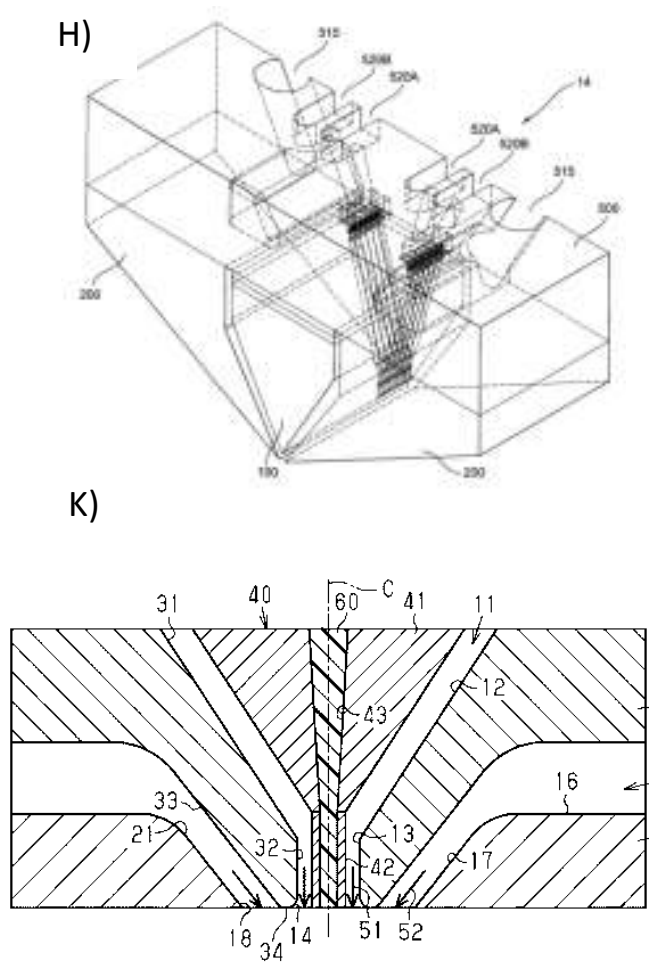

FIGURE 4: Summarization of the MB die designs described in Table 1. Figures are taken from the particular patents summarized in Table 1. 

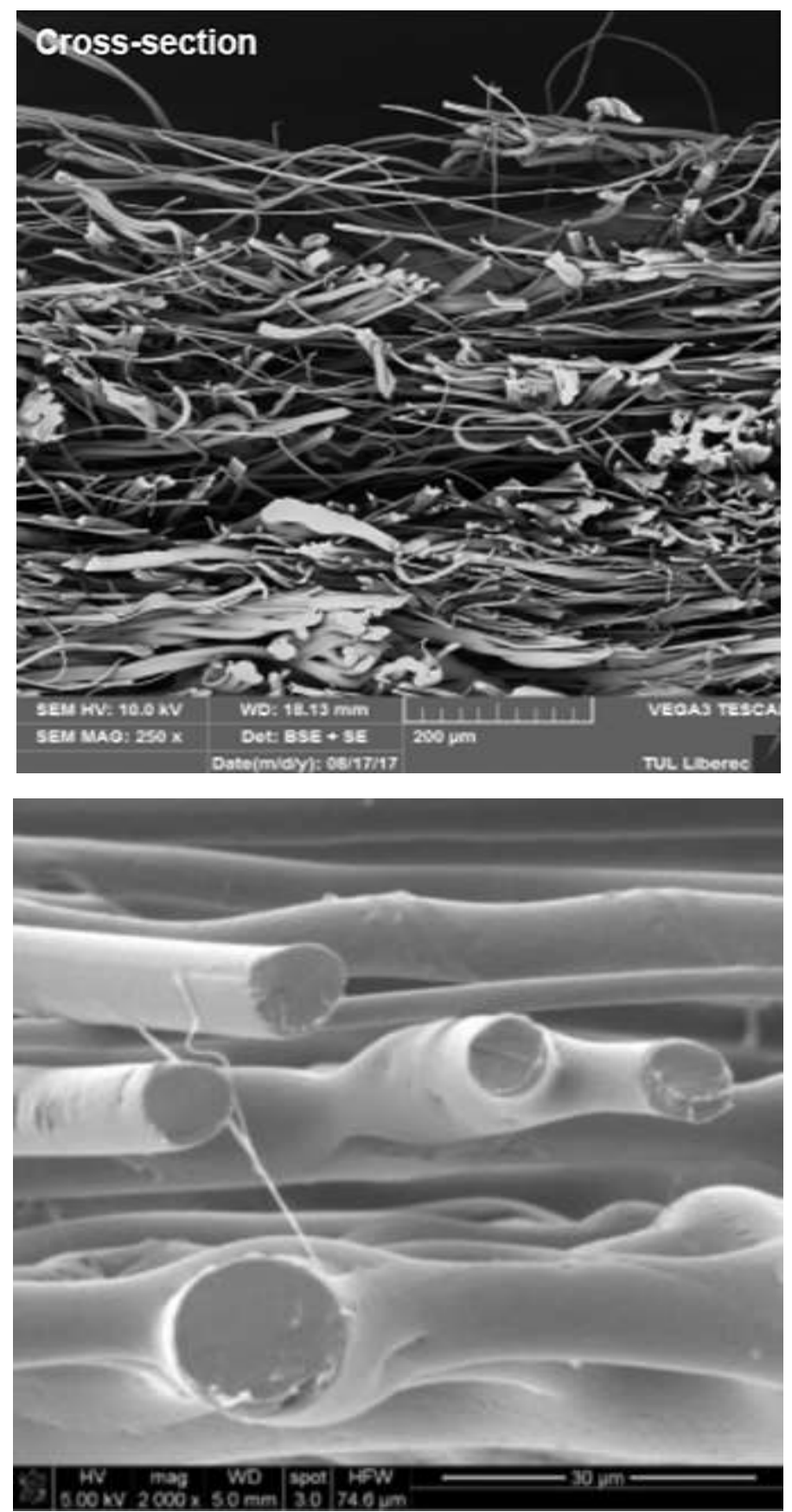

FIGURE 5: Cross-sectional photo of meltblown nonwoven (top: PP; Reprinted with permission from [92]. Copyright 2018, John Wiley and Sons; bottom: poly(lactide-coglycolide-co-trimethylene carbonate) copolymer; Courtesy of the open access Molecules journal and authors (J. Walczak, M. Chrzanowski, I. Krucińska,) - figure taken from [93]). 


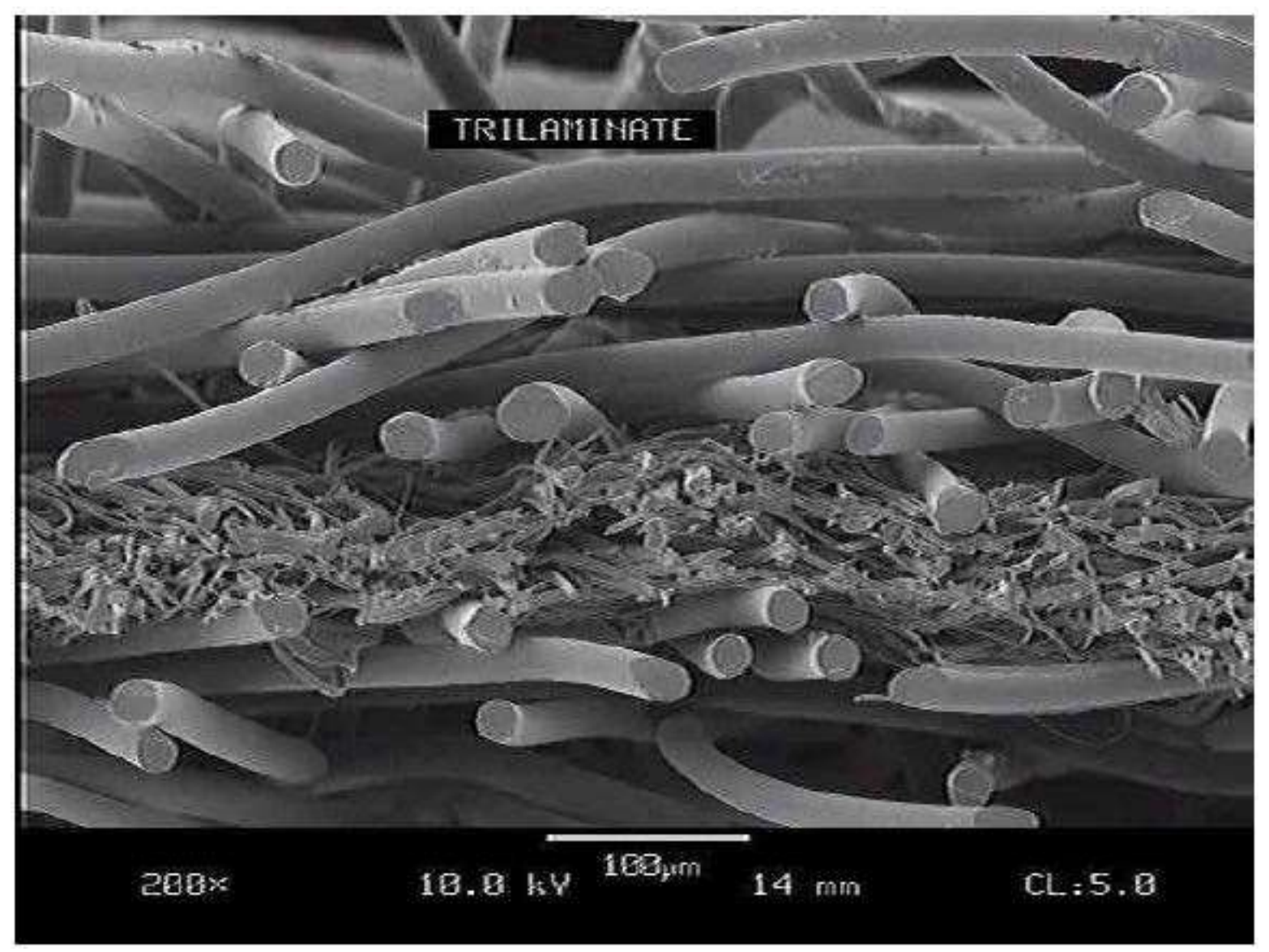

FIGURE 6: Spunbond-melt blown-spunbond structure. Reprinted with permission from [129]. Copyright 2003, SAGE Publications. 

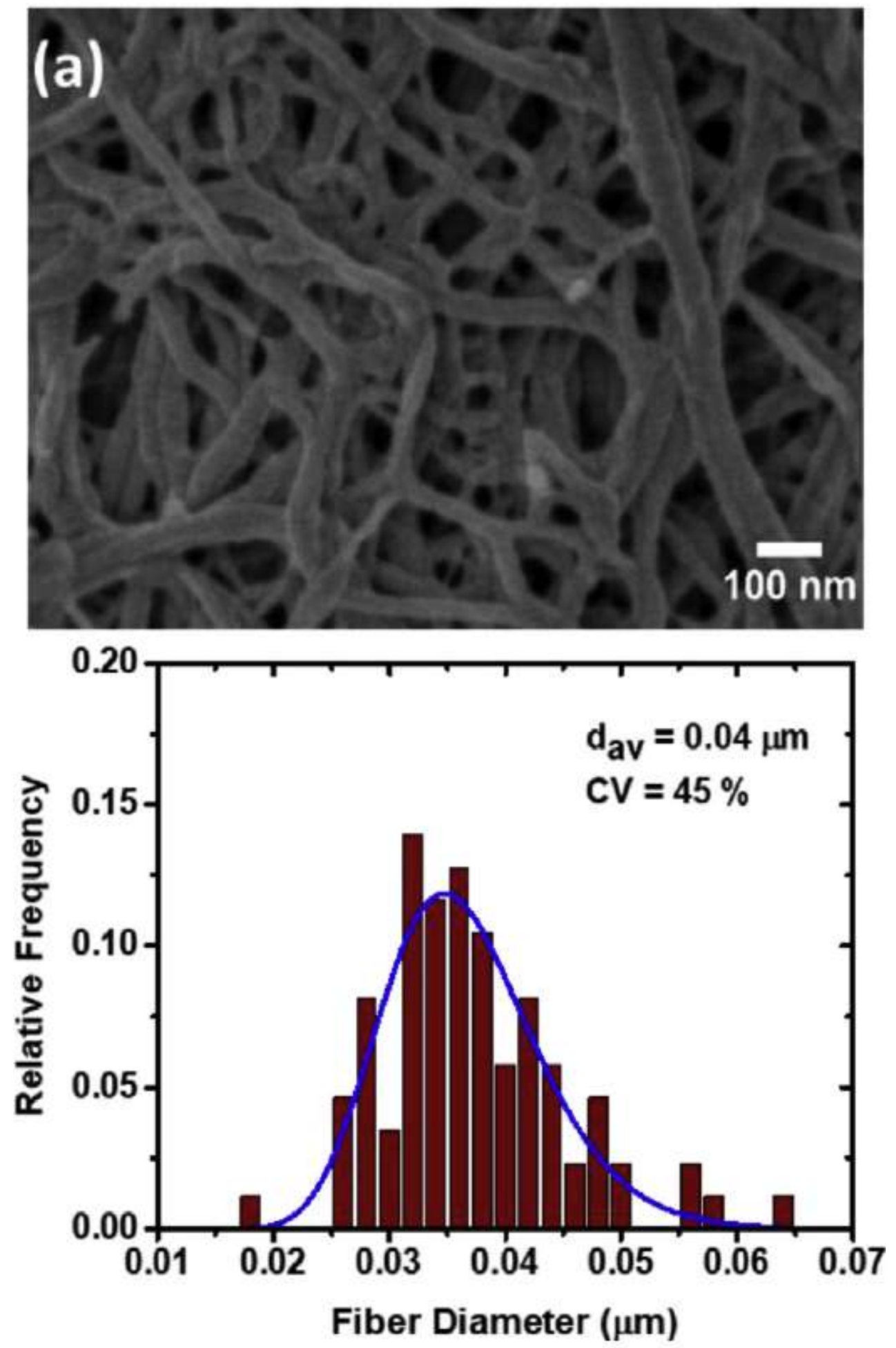

FIGURE 7: Morphology of polyvinylidene fluoride nanofibers extracted from polyvinylidene fluoride/sulfopolyester microfibers and their corresponding diameter distribution. Reprinted with permission from [96]. Copyright 2018, Elsevier. 

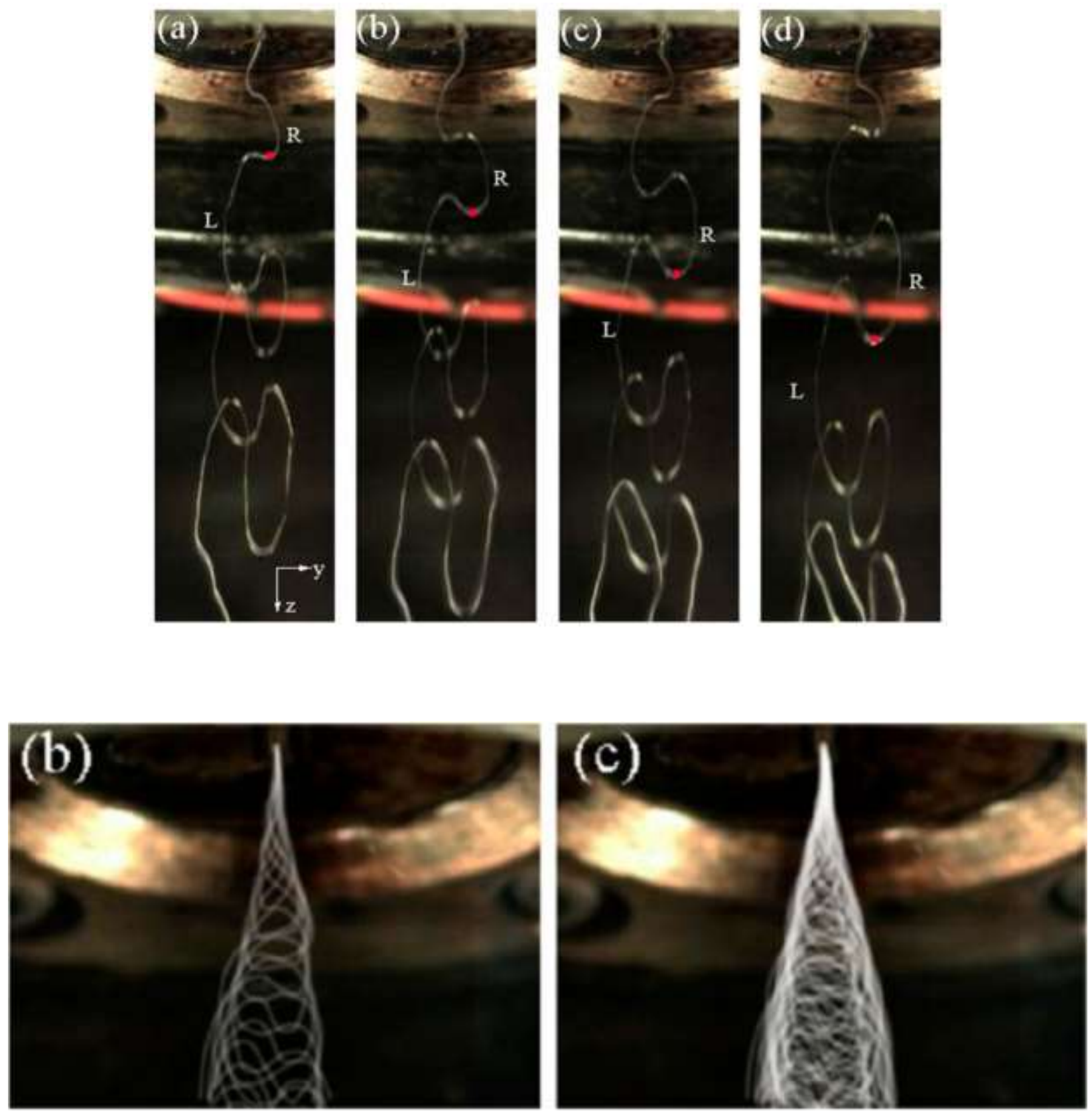

FIGURE 8: 2D fiber bending instability (top: time step is $0.67 \mathrm{~ms}$, image size is $17.9 \mathrm{~mm} \times 64.9 \mathrm{~mm}$; Reprinted with permission from [22]. Copyright 2014, American Chemical Society; bottom: ten and fifty paths overlapped, image size is $26.2 \mathrm{~mm} \times 19.6 \mathrm{~mm}$; Reprinted with permission from [144]. Copyright 2013, American Chemical Society). 

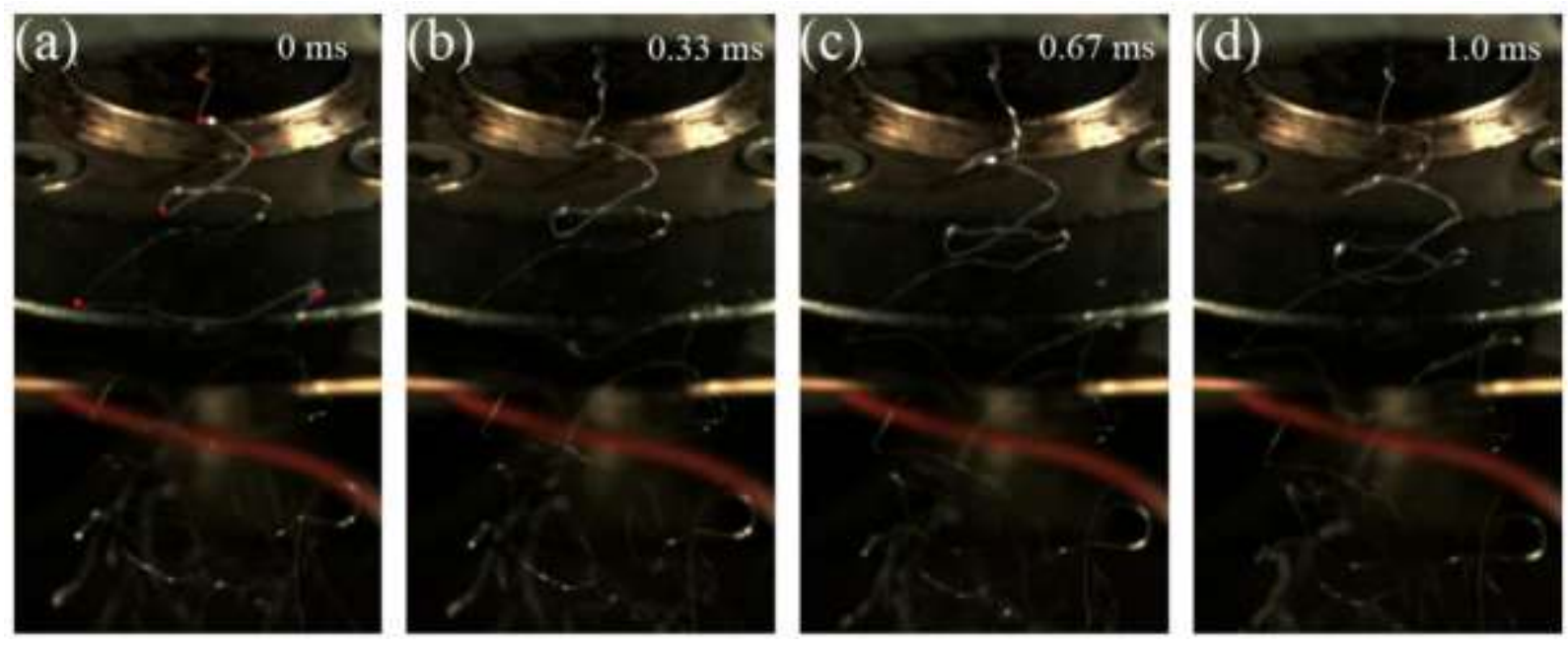

FIGURE 9: 3D fiber spiral motion, images size is s $26.3 \mathrm{~mm} \times 45 \mathrm{~mm}$ ). Reprinted with permission from [22]. Copyright 2014, American Chemical Society. 

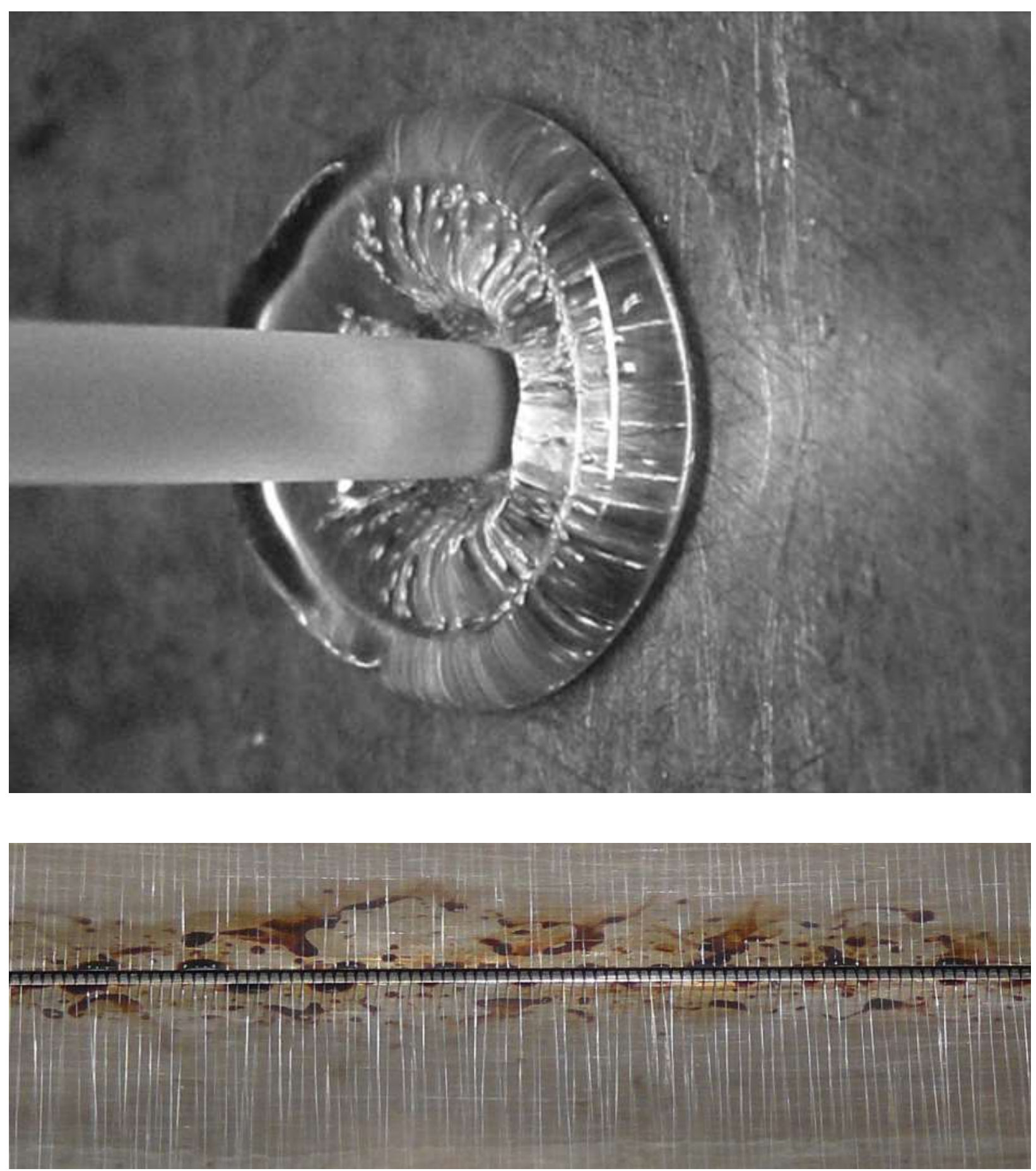

FIGURE 10: Die drool phenomenon occurring during extrusion of high density polyethylene (HDPE) melt through a single hole (top: Reprinted with permission from [155]. Copyright 2012, Elsevier.) and during melt blowing of PP via multi hole MB die under processing conditions (bottom). 


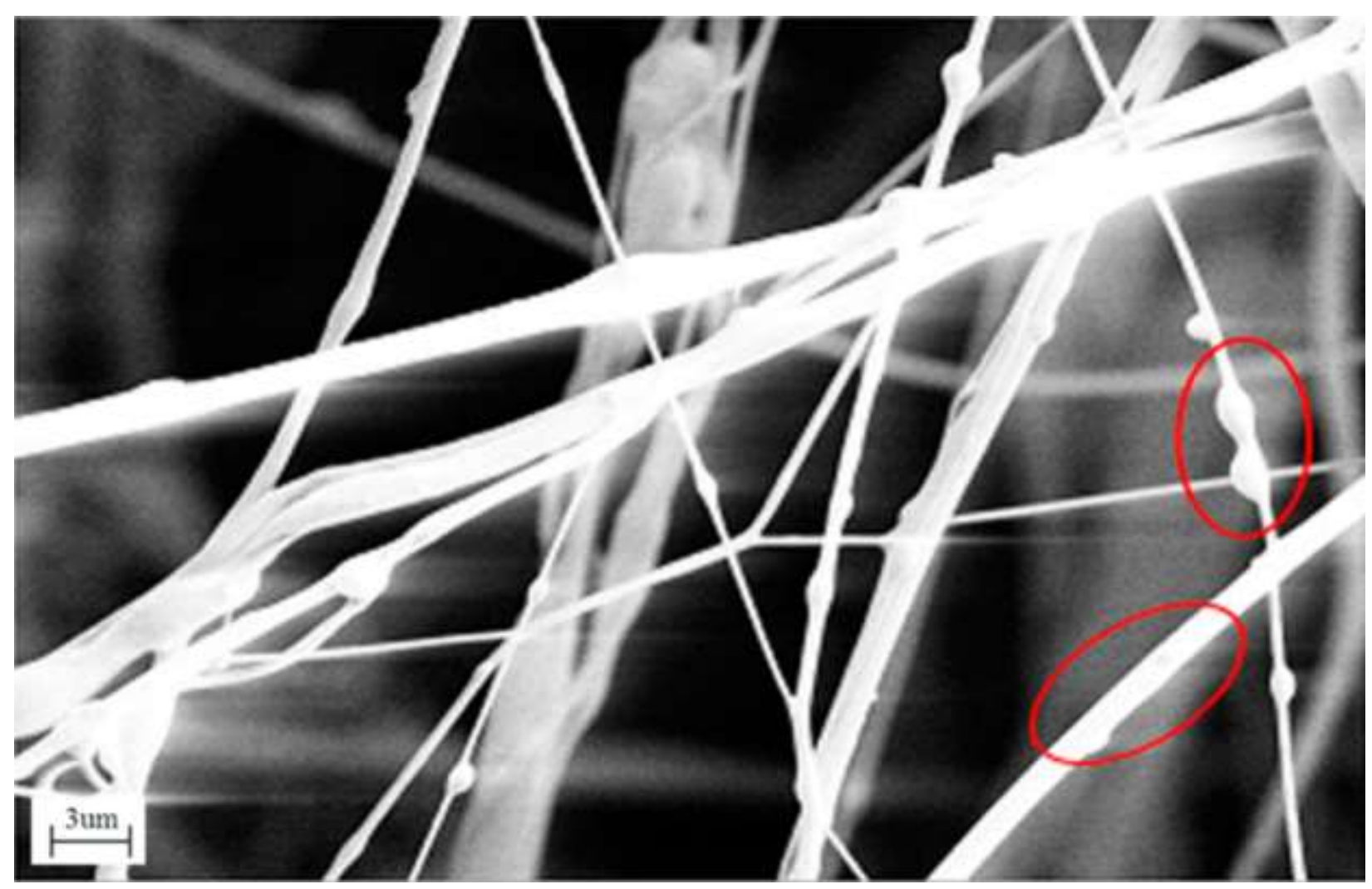

FIGURE 11: Fiber breakup. Reprinted with permission from [157]. Copyright 2016, American Chemical Society. 


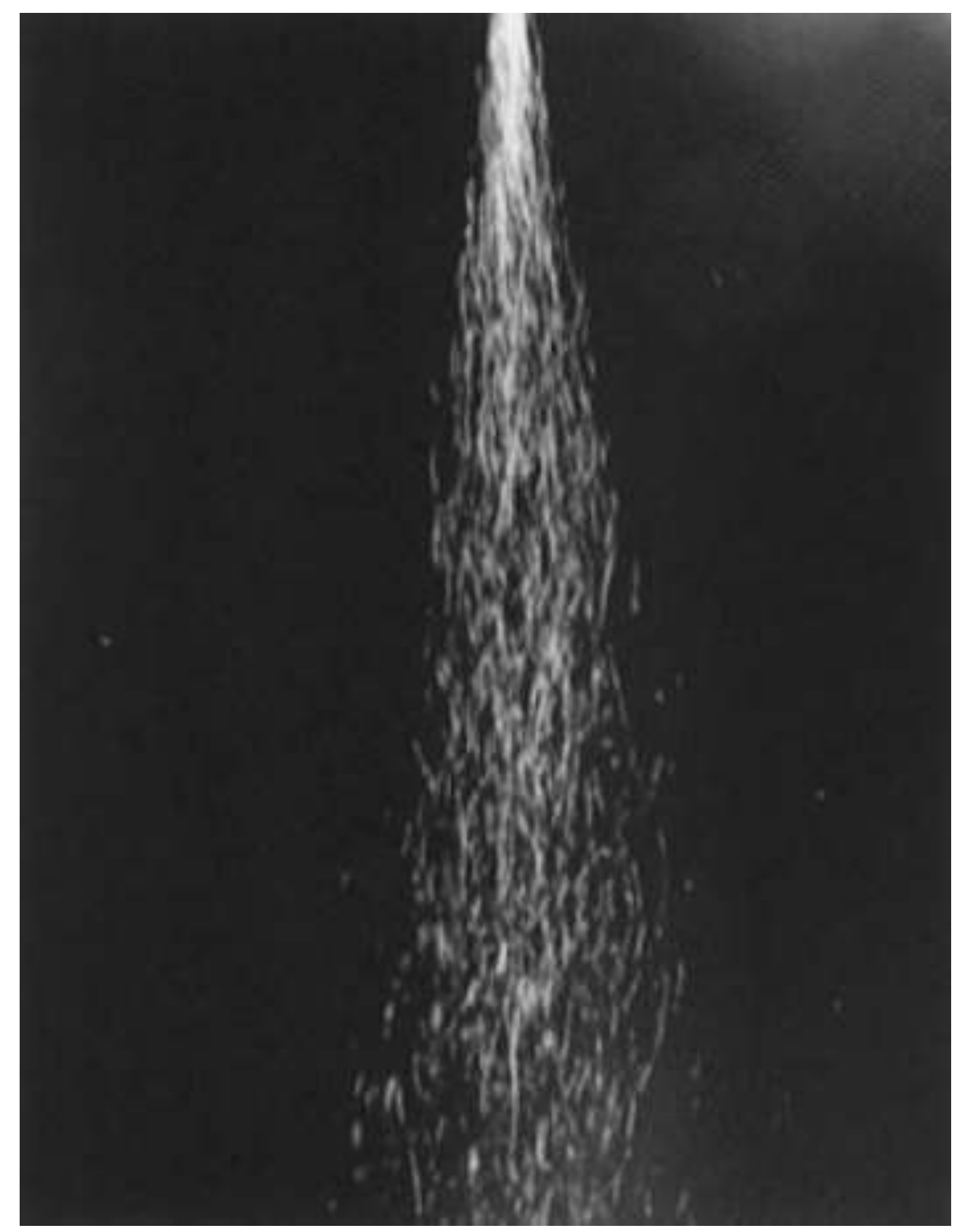

FIGURE 12: Melt spraying. Reprinted with permission from [141]. Copyright 1996, American Chemical Society. 

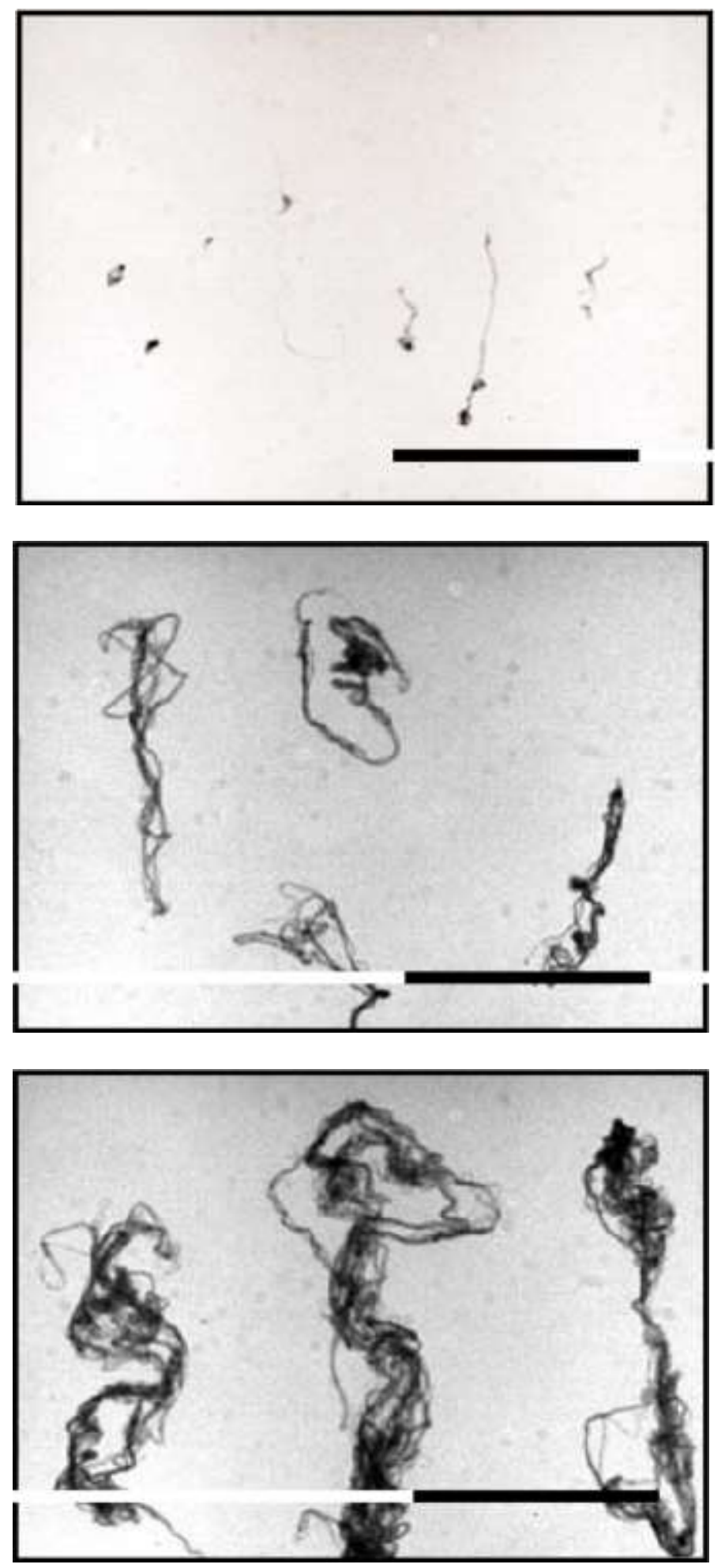

FIGURE 13: Flies collected at high (top), medium (middle) and low (bottom) DCD. The length of the black bar is $3.0 \mathrm{~cm}$. Reprinted with permission from [158]. Copyright 2002, SAGE Publications. 

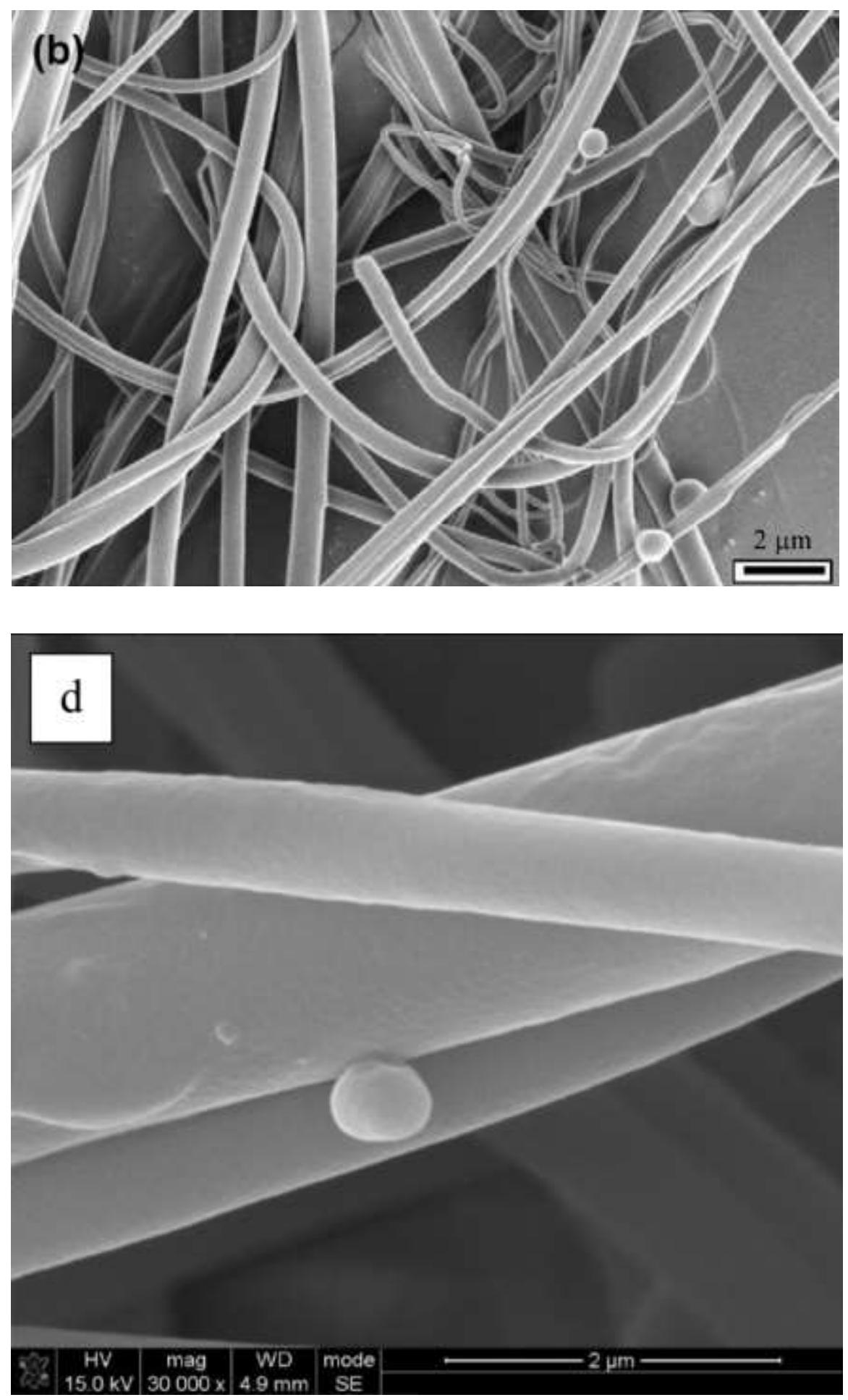

FIGURE 14: Visualization of isolated spherical particles on the produced mat. (top: Reprinted with permission from [18]. Copyright 2007, Elsevier; bottom: Courtesy of the open access Chemical and Process Engineering journal and authors (K. Majchrzycka, M. Okrasa, A. Brochocka and W. Urbaniak-Domagala) - figure taken from [162]). 

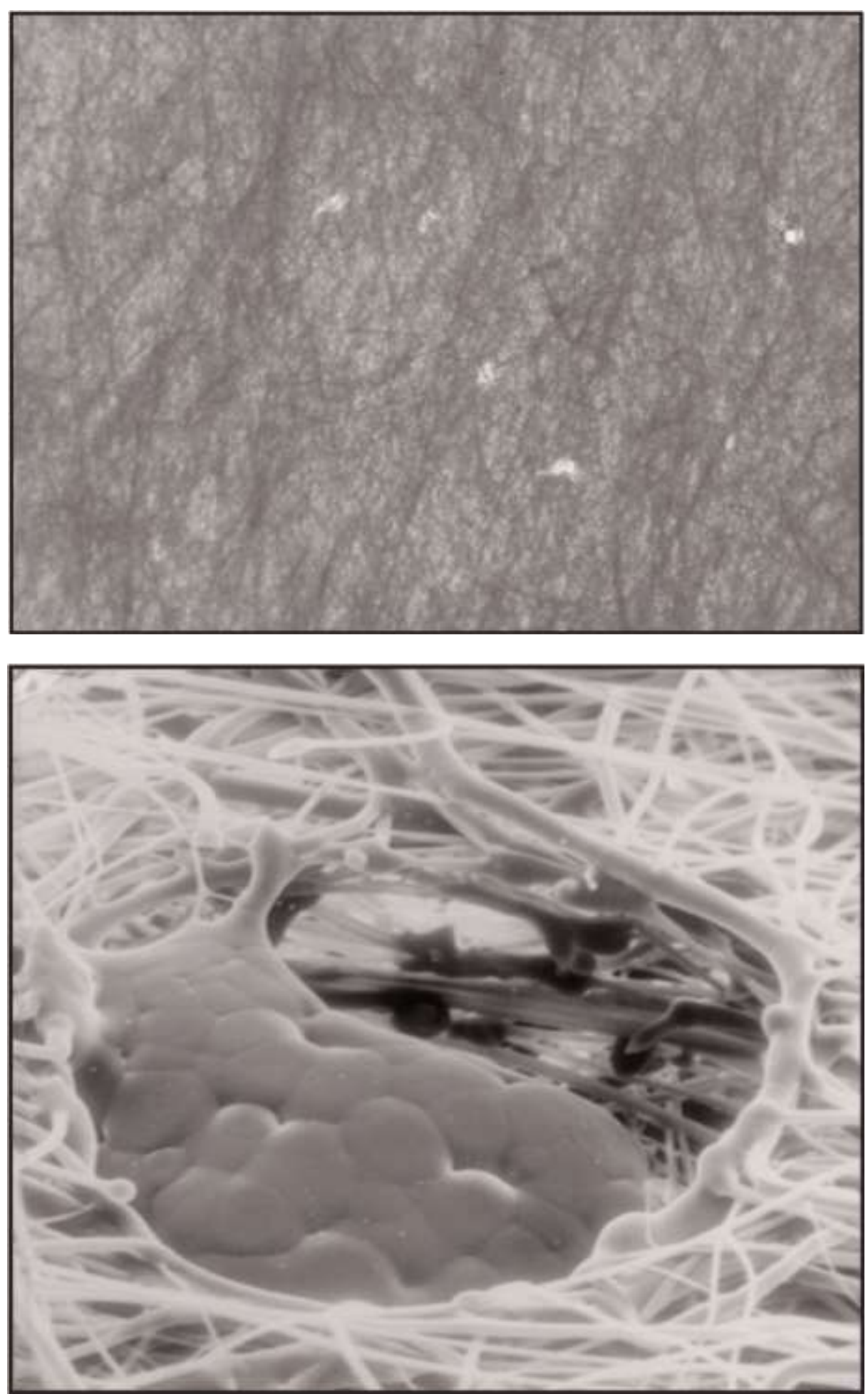

FIGURE 15: Damaged web due to shots (top) including detail view for one shot (bottom, image width $=371 \mu \mathrm{m}$ ). Reprinted with permission from [164]. Copyright 2005, SAGE Publications. 


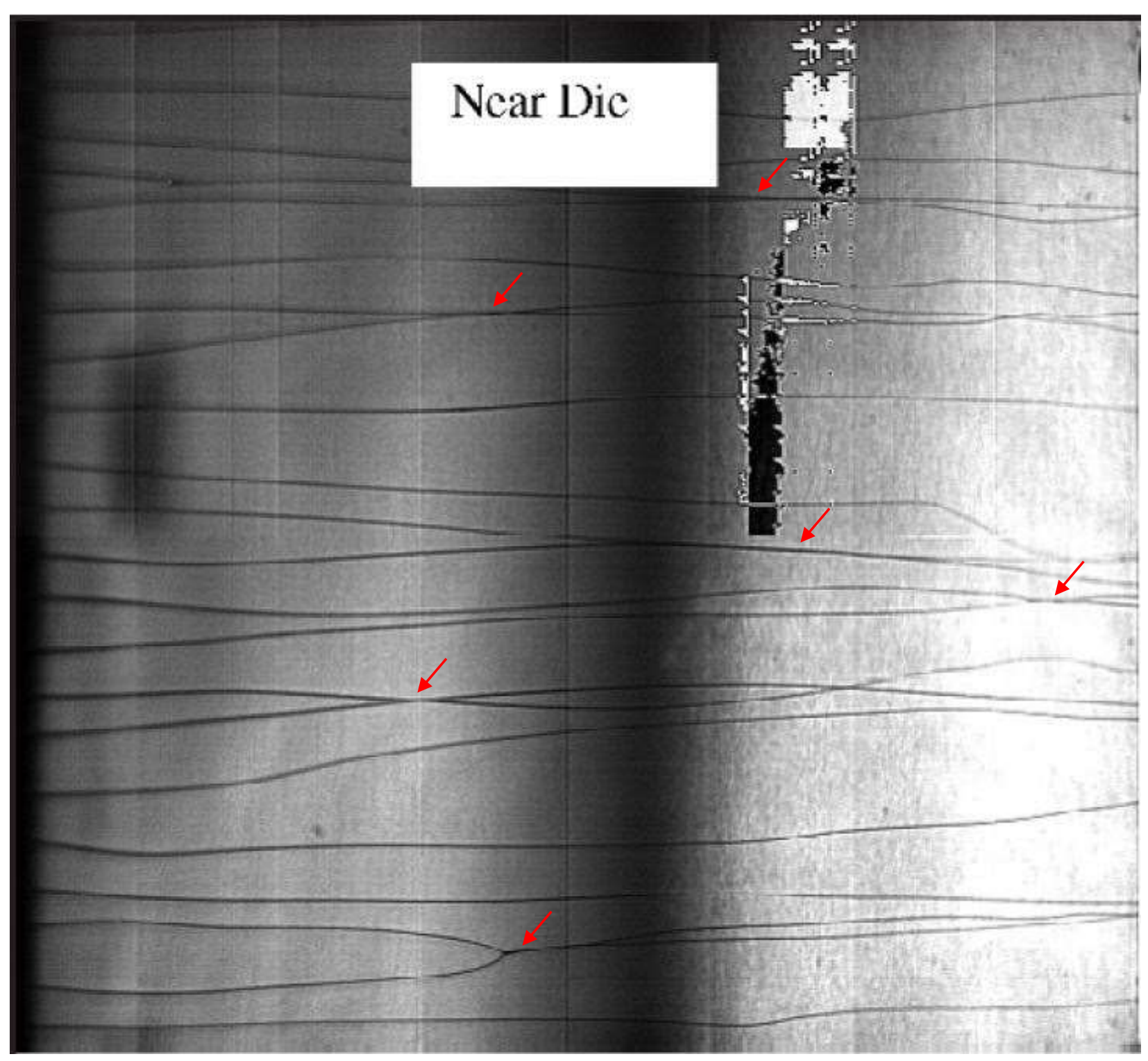

FIGURE 16: High speed photograph showing 400 MFI polypropylene melt fibers near the meltblown die face. Red arrows indicate locations where filaments are touching. Reprinted with permission from [14]. Copyright 2003, SAGE Publications. 


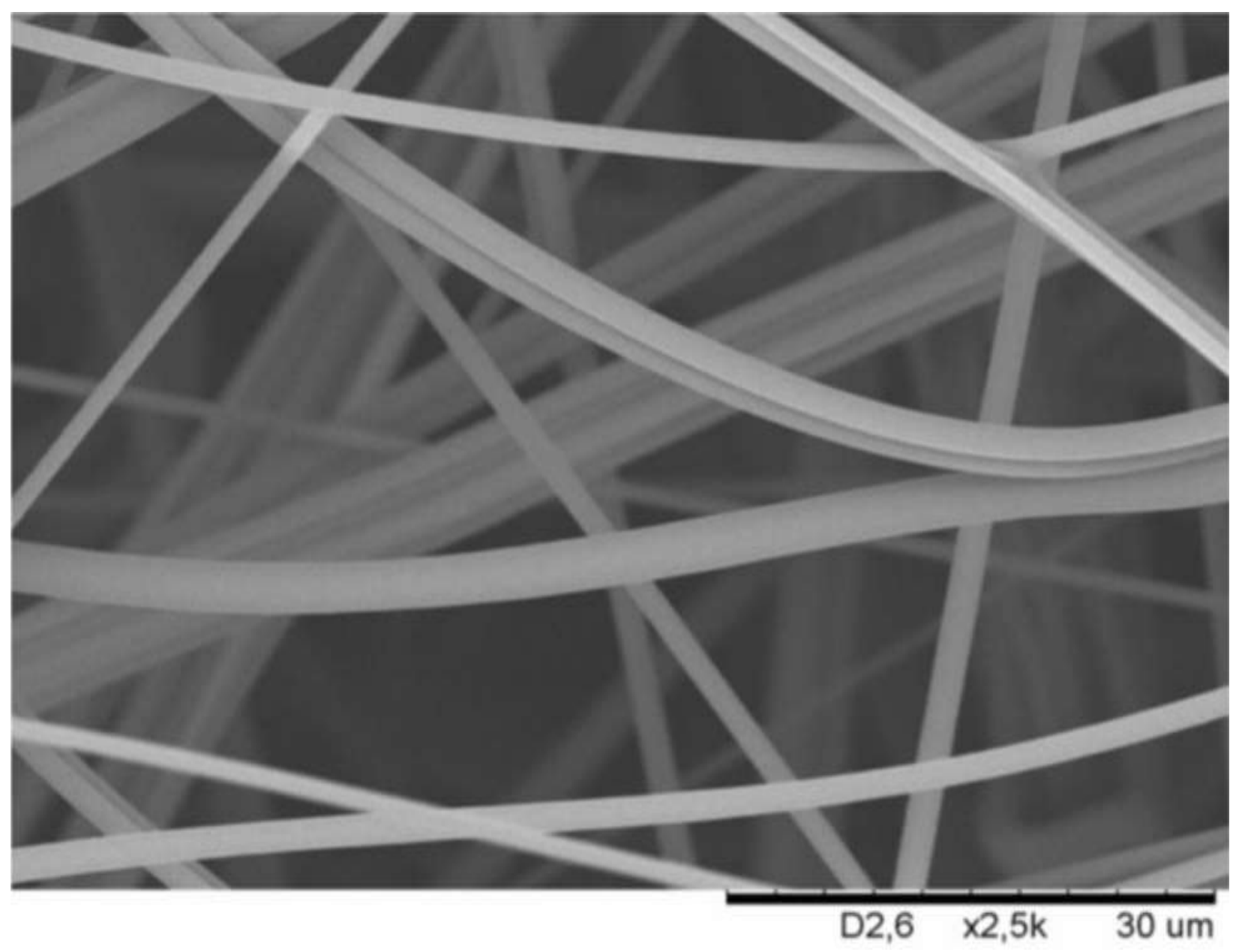

FIGURE 17: Jam effect. Reprinted with permission from [16]. Copyright 2019, The Society of Rheology. 

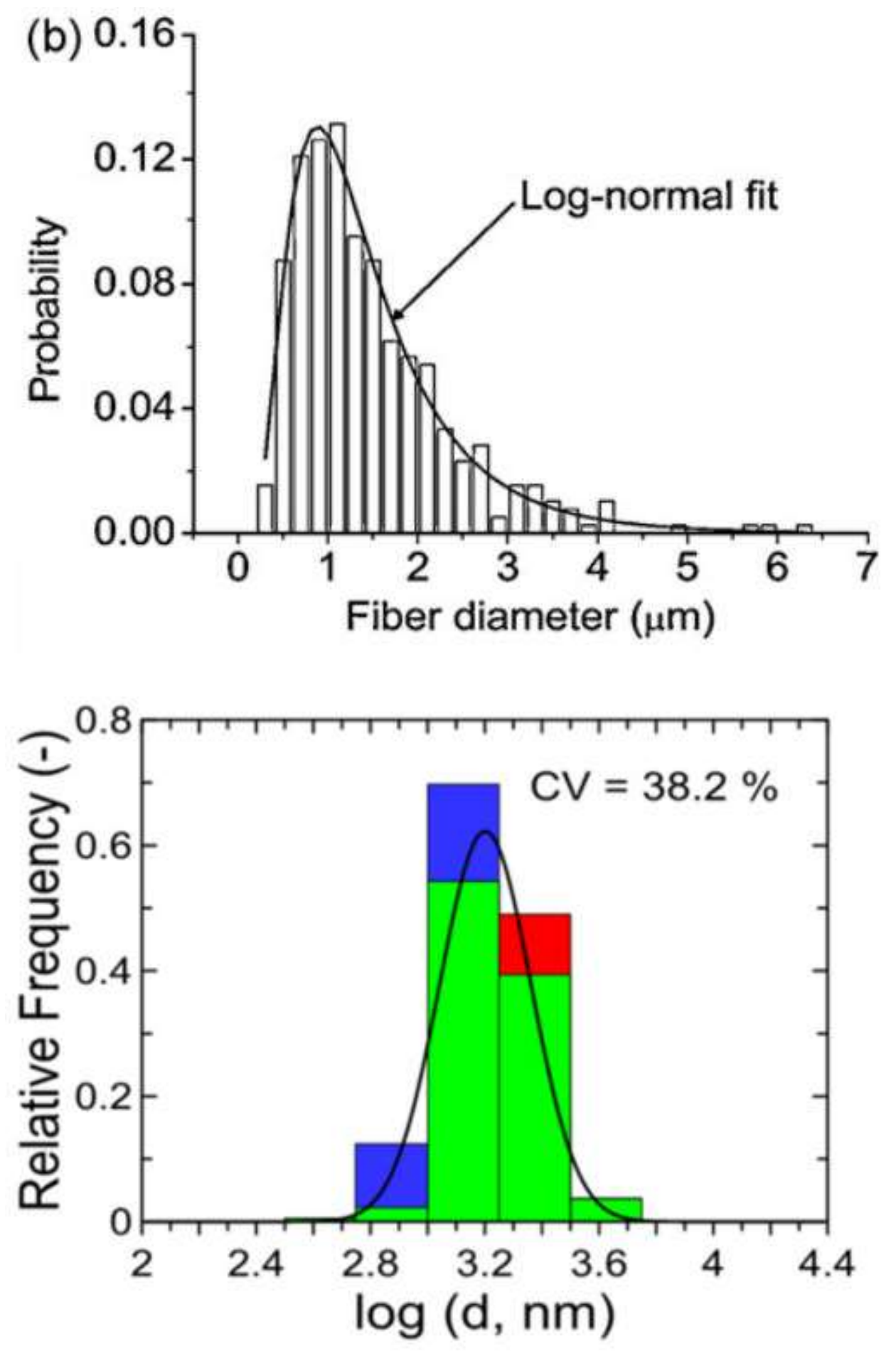

FIGURE 18: Typical fiber diameter log-normal distribution for MB nonwoven (top: single hole die; Reprinted with permission from [23]. Copyright 2010, Elsevier; bottom: multi-holes die; Reprinted with permission from [16]. Copyright 2019, The Society of Rheology). 

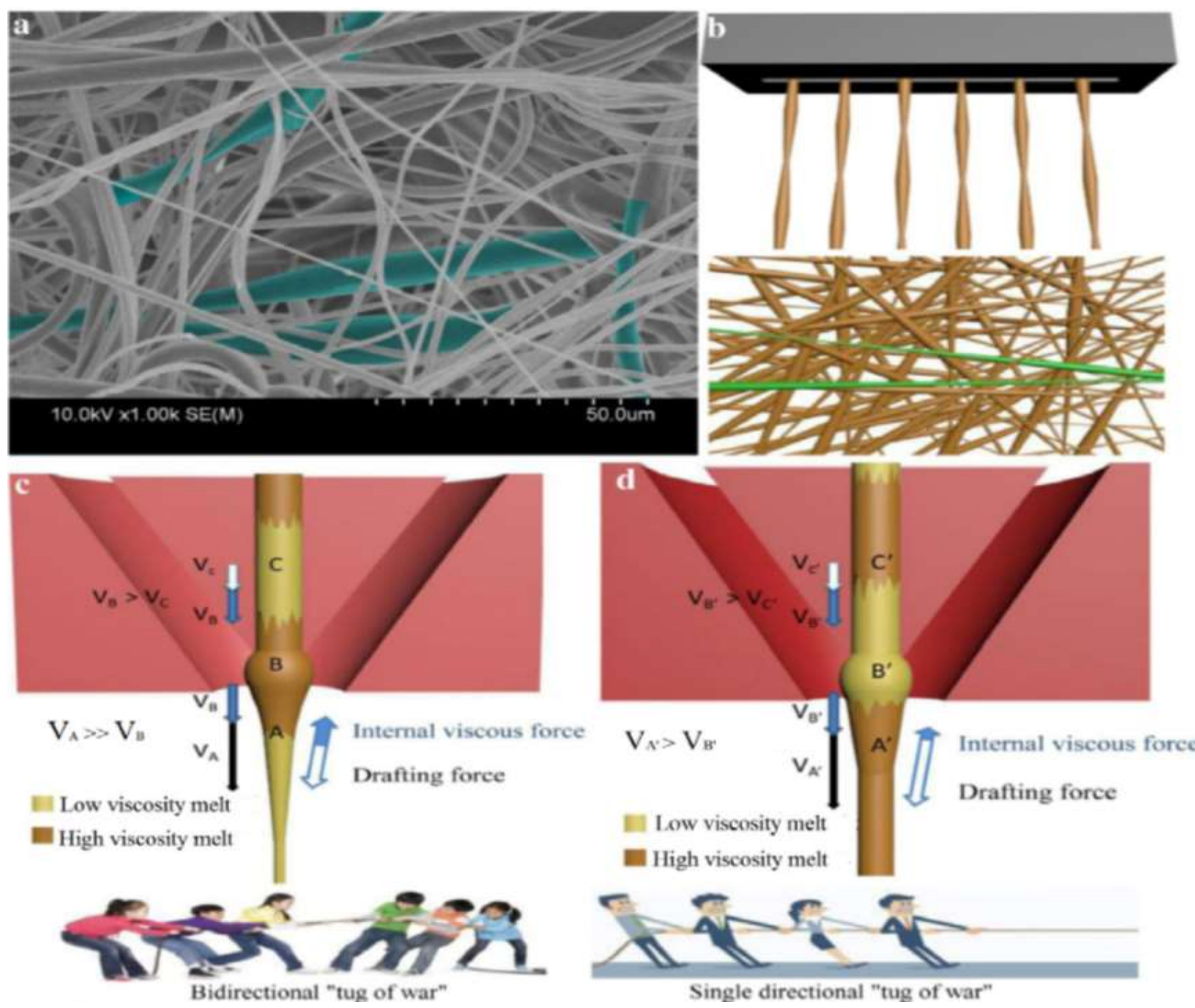

FIGURE 19: SEM image of PP/PS nonwoven (a); Formation principle of PP/PS membrane (b $\sim \mathbf{d})$. Reprinted with permission from [9]. Copyright 2019, Elsevier. 


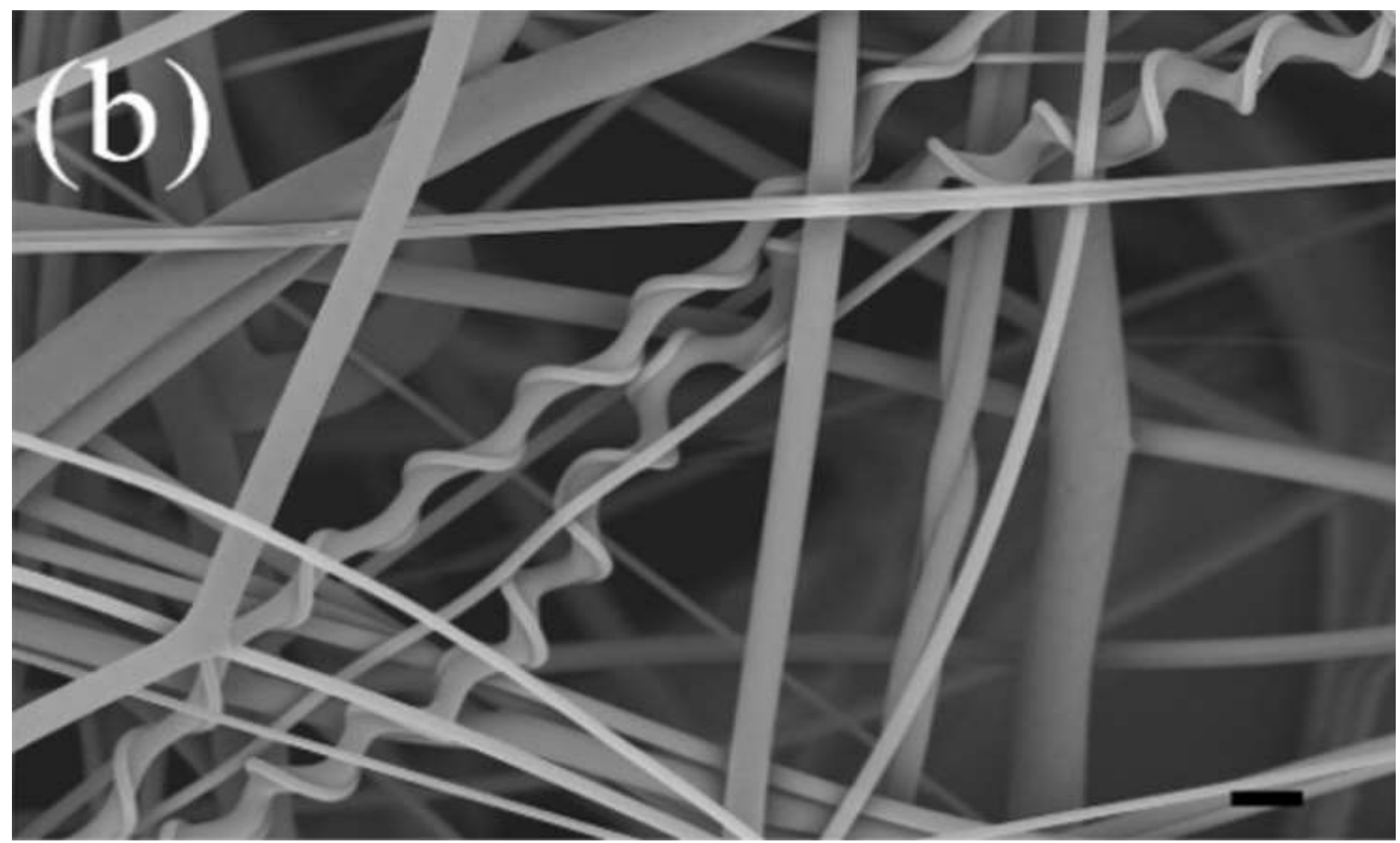

FIGURE 20: SEM image of PP/TPU nonwoven having the helical fiber with a threedimensional spiral shape. The black scale bars represent $10 \mu \mathrm{m}$ [169]. Reprinted with permission from [169]. Copyright 2018, John Wiley and Sons. 